\title{
Türkiye Mevduat Bankalarının Finansal Performans Analizi: Amerika Ticari Bankalarıyla Karşılaştırmalı Bir Bakış
}

\section{Comparative Analysis of the Financial Performance Between Turkish and American Commercial Banks}

\author{
Fatma ALDIRMAZ AKKAYA ${ }^{1}$ (D)
}

\section{öz}

Kaynak dağılımını belirleyen bankacılık sektörü, reel ekonominin ve finans sektörünün gelişimi için büyük önem arz etmektedir. Bu durum, bankacılık sektörünün sürekli olarak güçlü bir performans göstermesini ve beklenmeyen risklere karşı dayanıklı olmasını gerektirmektedir. Bu nedenle çalışmada öncelikle, Türkiye'de 2008-2018 yılları arasında kesintisiz faaliyet yürüten mevduat bankalarının finansal performanslarıyla, Amerika'da faaliyet gösteren ticari bankaların performans karşılaştırmalarının yapılması, ardından mevduat bankalarının ayrıntılı performans analizinin yapılması amaçlanmıştır. Uluslararası finans piyasalarında CAMELS Derecelendirme ve Performans Analizi yöntemi yaygın kullanım alanına sahip olduğu için analiz ve karşılaştırma için tercih edilmiştir. Araştırmada, hem Amerika ticari bankaları ile yapılan finansal performans karşılaştırması sonucunda hem de sadece Türkiye mevduat bankalarının finansal analizi sonucunda, Türkiye mevduat bankalarının, kabul edilebilir sınırlar dâhilinde olsa da, finansal performansla ilgili sorunlar yaşadığı ve olası şoklara karşı yeterince savunma geliştiremeyeceği tespit edilmiştir. Çalışmada ayrıca, genel olarak Türkiye mevduat bankalarının kredi ve alacaklarının yüksek olduğu ve bankaların bunların takibinde yetersiz kaldığı tespit edilmiştir. Bu sorunun giderilmesi halinde, bankaların diğer problemlerini azaltacağı düşünülmektedir.

Anahtar kelimeler: Bankacılık sektörü, CAMELS, Finansal performans analizi

JEL Sınıflaması: G00, G20, G21

\section{ABSTRACT}

The banking sector, which facilitates the safekeeping and distribution of resources, is very important for the development

'Dr. Öğr. Üyesi, Erzincan Binali Yıldırım Üniversitesi, Kemaliye Hacı Ali Akın Uygulamalı Bilimler Yüksekokulu, Erzincan, Türkiye

ORCID: F.A.A. 0000-0003-2726-4746

Sorumlu yazar/Corresponding author: Fatma ALDIRMAZ AKKAYA,

Erzincan Binali Yıldırım Üniversitesi, Kemaliye Hacı Ali Akın Uygulamalı Bilimler Yüksekokulu, Erzincan, Türkiye

E-posta/E-mail: faldirmaz@erzincan.edu.tr

Başvuru/Submitted: 08.05.2020

Revizyon Talebi/Revision Requested: 08.06.2020

Son Revizyon/Last Revision Received: 09.06.2020

Kabul/Accepted: 08.07.2020

Atıf/Citation: Aldirmaz Akkaya, F. (2020). Türkiye mevduat bankalarının finansal performans analizi: Amerika ticari bankalarıla karşılaştırmalı bir bakış. İstanbul iktisat Dergisi - Istanbul Journal of Economics, 70(2), 303-338. https://doi.org/10.26650/ISTJECON2020-0015 
of the real economy and financial sector. This requires the strong and consistent performance of the banking sector and requires it to be capable of withstanding unexpected risks. This study aimed to firstLY establish a performance comparison between Turkish and American commercial banks which operated uninterrupted from 2008-2018 and then to present detailed financial performance analysis of the Turkish commercial banks. The CAMELS rating and performance analysis method was chosen for analysis and comparison, given its widespread use in international financial markets. As a result of both the financial performance comparison with the American commercial banks and the financial analysis of only the Turkish commercial banks, it was determined that the Turkish commercial banks, although within acceptable limits, have problems related to financial performance and have not developed sufficient defense against possible shocks. The research also revealed that the loans and receivables of the Turkish commercial banks have been at high level and it was determined that the banks have insufficiently followed these loans. If this problem is resolved, it is believed that it will reduce other issues that the banks face.

Keywords: Banking sector, CAMELS, Financial performance analysis

JEL Classification: G00, G20, G21

\section{EXTENDED ABSTRACT}

This study aimed to firstly establish a performance comparison between Turkish and American commercial banks. It will then present a detailed financial performance analysis of the Turkish commercial banks with a wider range of financial ratios, and finally, it will identify the issues which cause poor performance in the Turkish banks, offering a suggested solution. The CAMELS rating and performance analysis method was chosen for analysis and comparison, given its widespread use in international financial markets. Within this scope, the analysis was carried out using financial ratios for 24 Turkish commercial banks which operated uninterrupted from 2008 to 2018, using the data published by The Banks Association of Turkey in comparison to financial ratios for the American commercial banks that operated uninterrupted during the same time, with data published by the Federal Deposit Insurance Corporation.

As a result of the performance analysis comparison between American and Turkish commercial banks, the American commercial banks have shown a generally strong financial performance, with 1-2 points of the CAMELS score, whereas the Turkish commercial banks have generally been within acceptable limits, with 3 points of the CAMELS score. This means that the Turkish banks have issues with financial performance and have not developed sufficient defense against possible shocks. In the examination made on the basis of CAMELS components, it was 
observed that in comparison of asset quality, the Turkish banks have lent high rates of loans but have been inadequate in recycling loans. In management quality comparison, it was seen that the ratio of operating expenses to the total loans and receivables of the Turkish banks have been high and have increased to high levels of risk, especially in 2018. In a comparison of adequate liquidity, it was observed that the Turkish banks have very high risks in terms of liquidity and they have maintained this level of risk. In the sensitivity to market risk comparison also, it was observed that the Turkish banks have high risk.

In performance analysis of the Turkish deposit banks based on CAMELS index values, it was concluded that the banks have experienced some difficulties. Although it is within acceptable limits, they could be vulnerable in times of crisis. When the banks were evaluated on the basis of groups, it was observed that the best financial performance indicator among the public capital banks was of Halk bank, whereas Ziraat bank recorded a performance decrease in 2018. Among the private banks, it was observed that the best performance indicator was of Adabank, whereas Iş and Yapi Kredi bank recorded a performance decrease in 2018. Among the foreign banks, it was observed that the best performance indicator has been in Citibank, whereas Burgan Bank, QNB Finansbank, and ICBC Turkey bank have continued their performances at very high risk levels. It was also observed that Denizbank returned to very high risk levels in 2018.

When banks with high risk levels were analyzed separately, it was observed that these banks have generally faced liquidity problems, decreased their operating income in total assets, increased their total loans and receivables, and increased their non-performing loans.

Nearly the same results were obtained in this study, both as a result of the performance comparison with the American banks and as a result of performance analysis of only the Turkish banks. Therefore, it is advised that the Turkish commercial banks should primarily practice caution regarding loans and receivables, and when return of loans and receivables are at appropriate levels, it is believed that this will simultaneously reduce liquidity and management quality problems. 
This study has several important limitations. The research examines only commercial banks and the international comparison was only with the American commercial banks. Another limitation is the data in this research being from a certain time period only. Future studies that cover the whole of the banking sector and perform international comparisons with additional countries will be important for the establishing the testability of this study. This study is expected to contribute to the development and expansion of the literature and also to assist professional practitioners in the banking industry. 


\section{Giriş}

Bankacılık sektörü diğer ekonomik sektörlerden farklı olarak kaynak dağılımını belirleyen finansal aracılık işlevini üstlenmektedir. Bu nedenle bankacılık sektörünün, ülkelerin ekonomik gelişiminde merkezi bir konumu bulunmaktadır ve varlık kalitesi ile büyüklüğü önem arz etmektedir (Emiral, 2002, s. 1). Gelişmiş ülkelerde bankacılık sektörü aktif büyüklüğü ortalaması gayri safi yurt içi hasılalarının (GSYH) yaklaşık olarak 3 - 3,5 katı üzerinde iken, gelişmekte olan ülkelerde yaklaşık olarak 1 - 1,5 katı üzerindedir (Keskin, İnan ve Ünsal, 2019, s. 72). Grafik 1'de ülkemizde bankacılık sektörünün temel göstergelerinin ülkemiz GSYH'sine oranları görülmektedir. Buna göre, 2008-2018 yıllarını kapsayan 10 yıllık süreçte en yüksek GSYH 2014 yılında gerçekleşmiştir. Bankacılık sektörü aktif büyüklüğü 2015 yılına kadar GSYH'nin üzerine çıkmamıştır. 2015 yılında 1,01 seviyesine ulaşan bankacılık sektörü aktif büyüklügü, 2016 ve 2017 yıllarında 1,05'e ulaşmış, 2018 yılında ise 1,04 oranına düşmüştür. Bu oranlar Türkiye Bankacılık Sektörü aktif büyüklüğünün gelişmekte olan ülkelerin ortalamalarına ulaştığını ve büyüme potansiyelinde olduğunu göstermektedir. Ancak, GSYH'deki küçülme oranlarının buna sebep olduğu da söylenebilir. Nitekim en yüksek aktif büyüklüğüne sahip olan 2017 yılı aktif büyüklüğünün 2014 yılı GSYH'sine oranının \%99 olduğu grafikte görülmektedir. Grafikte ayrıca mevduat dışı borçlar ve kredilerin GSYH'ye oranla artış eğiliminde olduğu görülmektedir. 


\section{Grafik 1. Türkiye Bankacılık Sektörü Temel Göstergelerinin GSYH'ye Oranları ${ }^{1}$}

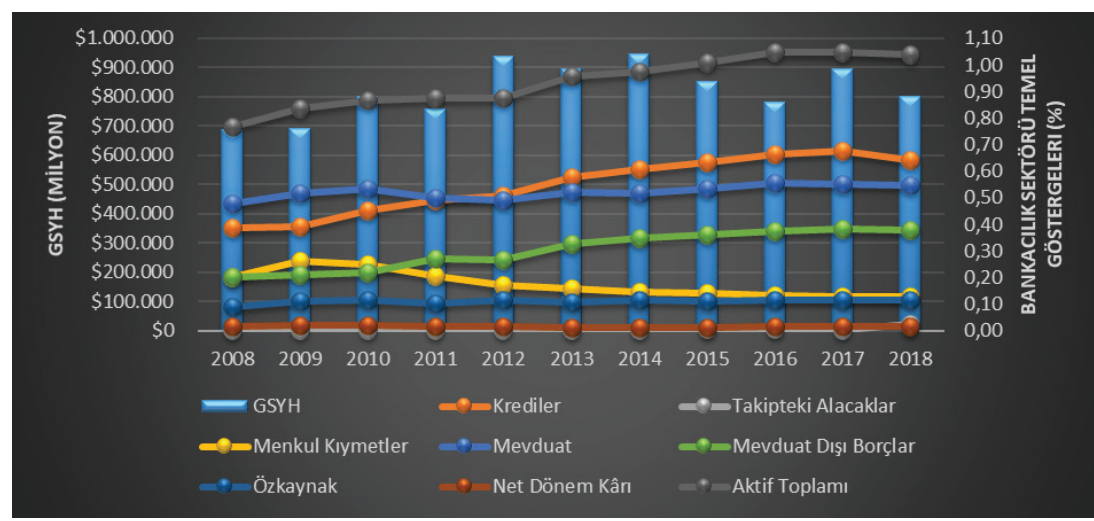

Kaynak: BDDK² ve TUiK 2 verilerinden faydalanılarak yazar tarafından tasarlanmıştır.

Diğer taraftan ülkemizde finans sektörünün temel yapısı, gelişmekte olan ülkelerin birçoğunda da olduğu gibi, bankacılık temeline dayanmaktadır (Kartal, 2018, s. 6; Ünal, 2014, s. 8; Öztürk, Barışık ve Kılıç Darıcı, 2010, s. 96). Grafik 2'de ülkemizde finans sektörünü oluşturan alt sektörler, 2008-2018 dönemini kapsayacak şekilde aktif büyüklükleri bakımından değerlendirilmiştir. Grafikte de görüldüğü gibi, bankacılık sektörünün aktif büyüklüğü 10 yıllık dönem boyunca \%90 seviyesinin altına düşmemiştir.

\footnotetext{
1 GSYH'nin yabancı para dönüşümünde reel USD kuru hesaplaması yapılmıştır. Hesaplamada nominal kur olarak 31 Aralık 2008 - 2018 tarihli Merkez Bankası efektif satış kurları kullanılırken, Türkiye ve Amerika enflasyon oranlarında 12 aylık ortalamalara göre değişimi esas alınarak hesaplanmış Aralık ayı değerleri kullanılmıştır (TCMB, 2020; TUIK 1 , 2020; www.inflationdata.com, 2020)

2 Bankacılık verileri 31 Aralık 2008-2018 tarihli BDDK verileridir.
} 


\section{Grafik 2. Türkiye Finans Sektörü Aktif Büyüklükleri}

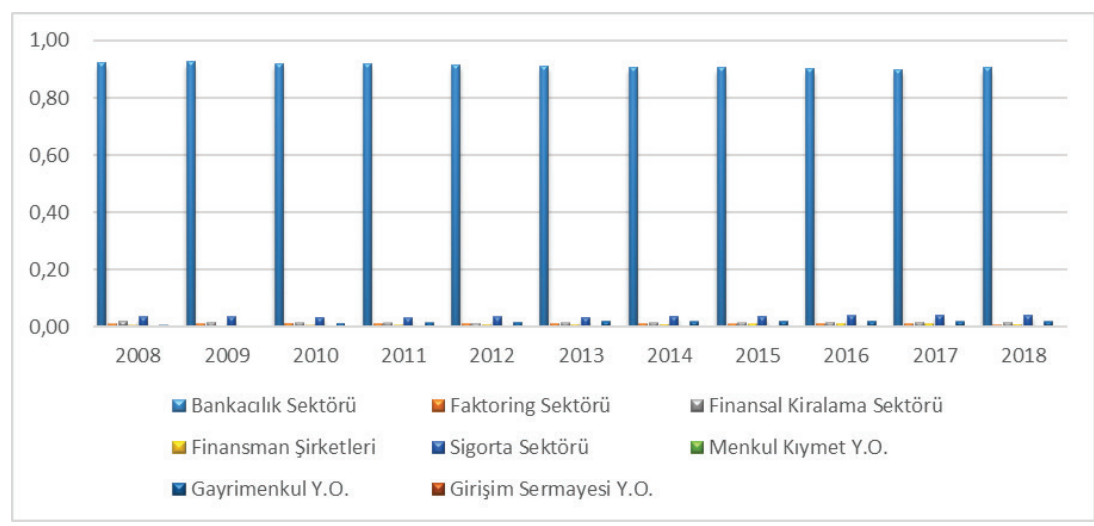

Kaynak: BDDK, Türkiye Sigorta Birliği, SPK verilerinden faydalanılarak yazar tarafından tasarlanmıştır.

Banka sektörünün finans sektörü içindeki etkinlik boyutunun bu derece yüksek olması, ülkemizde finansal istikrarın sağlanabilmesi ve sürdürülebilmesi için bankacllık sektörünün önemini arttırmaktadır. Bu nedenle bankacılık sektörünün sürekli olarak sağlam, güçlü ve dayanıklı bir performans göstermesi gerekmektedir (Kartal, 2018, s. 6). Tablo 1 ve Grafik 3'te bankacılık sektörü verileri temel göstergeler bakımından incelenmiştir.

Tablo 1: Bankacılık Sektörü Temel Göstergeler ${ }^{3}$

\begin{tabular}{|c|c|c|c|c|c|c|c|c|c|c|c|c|}
\hline \multicolumn{13}{|c|}{ (milyon USD) } \\
\hline Temel Göstergeler & 2008 & 2009 & 2010 & 2011 & 2012 & 2013 & 2014 & 2015 & 2016 & 2017 & 2018 & Eğim Grafiği \\
\hline Krediler & 264.752 & 271.339 & 363.523 & 371.514 & 475.493 & 518.935 & 574.113 & 542.156 & 518.683 & 603.494 & 515.859 & \\
\hline Takipteki Alacaklar & 2.047 & 2.478 & 2.240 & 2.128 & 3.475 & 3.480 & 4.403 & 4.411 & 3.926 & 3.809 & 20.824 & \\
\hline Menkul Kiymetler & 139.774 & 181.672 & 198.995 & 155.039 & 161.534 & 142.060 & 139.352 & 120.059 & 104.886 & 115.291 & 102.780 & \\
\hline Mevduat & 327.548 & 355.652 & 426.560 & 378.370 & 462.008 & 468.578 & 487.113 & 454.703 & 434.732 & 492.092 & 438.632 & \\
\hline Mevduat Dişı Borçlar & 137.989 & 144.099 & 176.343 & 205.400 & 249.207 & 293.753 & 328.367 & 310.240 & 292.223 & 341.762 & 303.651 & \\
\hline Özkaynak & 62.270 & 76.634 & 93.009 & 78.692 & 108.852 & 95.980 & 107.357 & 95.750 & 89.805 & 103.162 & 90.922 & \\
\hline Net Dönem Kârı & 9.670 & 13.948 & 15.289 & 10.796 & 14.074 & 12.220 & 11.388 & 9.512 & 11.224 & 13.992 & 11.660 & \\
\hline Aktif Toplamı & 527.808 & 576.385 & 695.913 & 662.462 & 820.067 & 858.310 & 922.836 & 860.693 & 816.760 & 937.015 & 833.206 & \\
\hline
\end{tabular}

Kaynak: BDDK verilerinden faydalanılarak yazar tarafından tasarlanmıştır.

Tablo 1'de en dikkat çekici kalem takipteki alacaklar olarak görülmektedir. On yıllık süreçte normal bir seyir izleyen takipteki alacaklar kalemi 2018 yılında

\footnotetext{
${ }^{3}$ Tablo 1'de dipnot 1'de bahsi geçen yöntemle hesaplanmış reel döviz kurları kullanılmıştır.
} 
yaklaşık olarak 5,5 kat oranında ani bir artış eğilimine girmiştir. Bununla birlikte krediler kalemi incelendiğinde, on yıllık süreçte 2017 yılına kadar sürekli artma eğiliminde olduğu ancak 2018 yılında azalma eğilimine girdiği görülmektedir. Diğer taraftan mevduat dışı borçlar kaleminde zaman zaman iniş ve çıkışlar gözlemlense de 2017 yılına kadar artış eğilimi görülmektedir.

\section{Grafik 3. Bankacılık Sektörü Temel Göstergelerinin Varlık Yapısı İçindeki Yeri ${ }^{4}$}

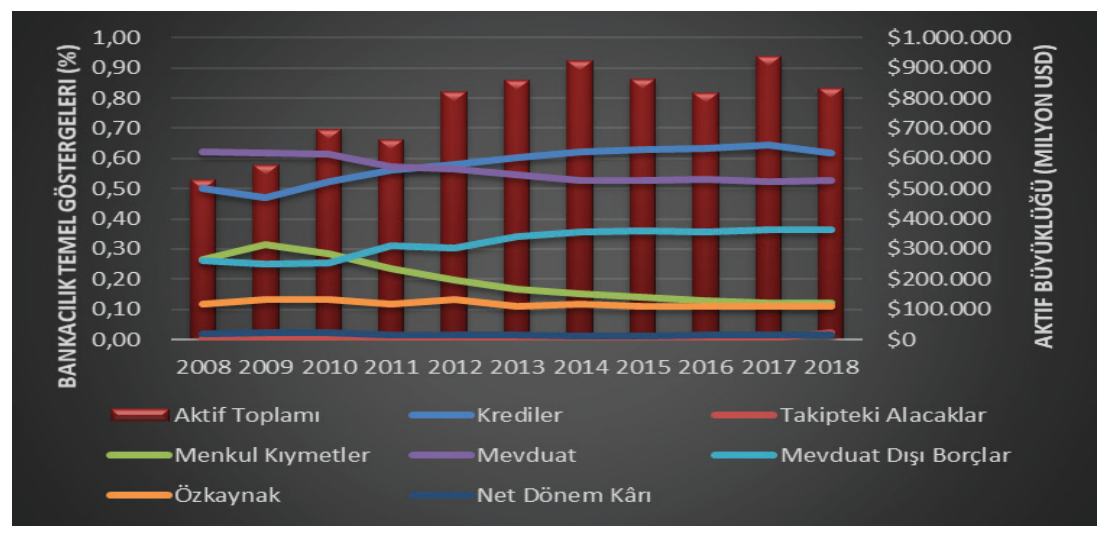

Kaynak: BDDK verilerinden faydalanılarak yazar tarafından tasarlanmıştır.

Grafik 3'te kredilerin varlık yapısı içindeki yerinin giderek arttığı ve \%60'ların üzerine çıtığı görülmektedir. Bununla birlikte mevduat dışı borçlarda da sürekli artış olduğu ve son yıllarda aktiflere oranının \%36'nın üzerine çıktığı görülmektedir. Takipteki alacaklarda görülen ani yükseliş, kredilerde ve mevduat dışı borçlardaki artış, bankacılık sektöründe risk ağılıklı varlıkların oranının giderek artmakta olduğunun göstergesidir denilebilir.

Bankacllık sektörünün temel göstergelerinde görülen bu eğilimlerin ve diğer finansal oranlarının normal düzeylerde olup olmadığının çeşitli performans analiz yöntemleriyle takip ve kontrolü yapılmalı ve ulaşılan uygun seviyelerin sürdürülebilirliği sağlanmalıdır. Uluslararası finans piyasalarında performans ölçümü ve denetimi için CAMELS Derecelendirme ve Performans Analizi Yöntemi yaygın kullanım alanına sahiptir. Bu nedenle bu çalışmada öncelikle Türkiye'de

\footnotetext{
${ }^{4}$ Grafikte dipnot 1'de söz edilen yöntemle hesaplanmış reel döviz kurları kullanılmıştır.
} 
2008-2018 yıllarında sürekli faaliyet gösteren mevduat bankalarının CAMELS performans analizi yöntemiyle Amerika'da faaliyet gösteren ticari bankalarla performans karşılaştırmasını yapmak amaçlanmaktadır. Araştırmanın ikinci aşamasında daha geniş kapsamlı finansal oranlarla Türkiye bankaları bazında performans analizi yapmak amaçlanmaktadır.

Çalışmanın bundan sonraki bölümlerinde öncelikle konu ile ilişkili literatür araştırmalarına yer verilecektir. Çalışmanın üçüncü bölümü araştırmaya yönelik bilgileri, analizi ve bulguları içerecektir.

\section{Literatür Taraması}

Uluslararası finans piyasalarında yaygın kullanım alanına sahip olan CAMELS Derecelendirme ve Performans Analiz Yöntemi, çok sayıda akademik çalışmada da kullanılmıştır. Bu çalışmada belli başl çalışmaların kısıtlarına ve sonuçlarına yer verilmiştir.

Majithiya ve Pattani (2010)'nin Hindistan'da özel bankalardan, kamu bankalarından ve kooperatif bankalarından birer örnek seçerek CAMELS performans derecelendirme yöntemiyle analiz yapmışlardır. Yapılan analiz, bankaların 2004-2009 yılları arasındaki faaliyetlerini kapsamaktadır. Analiz sonucunda özel sektörden seçilen bankanın 1., kamu sektöründen seçilen bankanın 2. ve kooperatif sektöründen seçilen bankanın ise 3 . olduğu sonucuna ulaşmışlardır.

Dang (2011), tez çalışmasında AIA (American International Assurance)'nın CAMEL yaklaşımıyla Vietnam'da bir bankanın 2007-2010 yıllarını kapsayan incelemesini yapmıştır. Araştırmada CAMEL derecelendirme sisteminin bankaların içeriden ve dışarıdan kapsamlı denetiminde önemli bir yeri olduğu ve bunun faydalı olduğu sonucuna ulaşmıştır. Ancak sistemin Vietnam'daki bankaları yakından takip edemediğini, bu nedenle bankaların üst yönetimi ile ilişkileri ve kredi zararı karşılığı oranlarını önemsememek gibi dezavantajlara sahip olduğunu belirtmiştir.

Bergendorff ve Osbäck (2017), yapmış oldukları tez çalışmasında Avrupa Komisyonu tarafından başlatılan Capital requirements directive (CRD IV)'in aktif 
büyüklüklerine göre belirledikleri Avrupa Birliği'nin en büyük 30 bankasını analiz etmişlerdir. Bankaların sermaye gereksinimine etkisini CAMELS derecelendirme sistemini kullanarak değerlendirmişlerdir. Çalışma 2011-2015 yılları verileriyle gerçekleştirilmiştir. Çalışmada yazarlar, bankalarda yeni sermaye gereklilikleri nedeniyle sermaye oranlarında belirgin bir artışın olduğu, kârlılık ve likiditenin ise tamamen sağlam bir bankacılık sektörü verilerini göstermediği sonucuna ulaşmışlardır. Yazarlar, kârlılık ve likiditenin hâlâ çok düşük olduğunu ancak bunun son durgunluktan kaynaklanabileceğini de belirtmişlerdir.

Desta (2016), Küresel Finans Dergisi'nin belirlediği en iyi 30 Afrika bankası arasından, 2012-2014 yılları verilerine tam ulaşabildiği 7 bankaya CAMEL bileşen ve bölüm derecelendirme yöntemini uygulamıştır. Analiz sonucunda bankaların sermaye yeterlilik rasyosu ve kârlılık yönünden güçlü ve tatmin edici olduğuna ancak varlık kalitesi, yönetim kalitesi ve likidite açısından yetersiz olduğuna ulaşmıştır. 2015 yılında Küresel Finans Dergisi tarafından en iyi bölgesel banka olarak seçilen Standard Bank of South Africa Ltd., Desta'nın yapmış olduğu analizde son sıradadır. Bu nedenle Desta çalışmasında hem bankalara hem de dergiye CAMEL yöntemini kullanmalarını önermektedir.

Masood, Ghauri ve Aktan (2016), Pakistan'da faaliyet gösteren 6 İslami bankanın 2015 yılındaki performanslarını CAMELS analiz yöntemiyle incelemişlerdir. Sonuç olarak 2 bankanın tatmin edici sonuçlar verdiğine ve diğer bankaların ise hassas nitelikte olduğuna ulaşmışlardır.

Zedan ve Daas (2017), Filistin ticari bankalarının 2015 yılı faaliyetlerini CAMEL derecelendirme yöntemiyle analiz etmişlerdir. Analizi 5 bankayla sınırlandırmışlardır ve analiz sonucunda 5 bankayı CAMEL derecelendirme puanına göre en iyi performanstan en kötü performansa doğru sıralamışlardır.

Keffala (2018), İtalya'daki 22 ticari bankanın 2005-2015 dönemine ait verilerini kullanarak, türev araçların bankaların CAMELS göstergeleri (sağlamlı̆̆ı) üzerindeki etkisini ölçmüştür. Analiz sonucunda CAMELS göstergelerinin çoğunun, özellikle ileriye dönük ve opsiyonlu türev araçlardan olumlu 
etkilendiğine ulaşmıştır. Yazar, bankaların türev araçları kullanmasının finansal sağlamlığı tehdit etmediğini belirtmiştir.

Türkiye bankacılık sisteminin analizine yönelik yapılan çalışmalar ise şu şekildedir;

Ateşoğlu Coşkun ve Karğın (2016), Türkiye'de gerçekleşen üç sınır ötesi banka satın almasının, söz konusu bankaların finansal performanslarına olan etkilerini; satın alınma öncesi üç yıllık ve sonrası üç yıllık dönemi kapsayacak şekilde CAMELS analiz yöntemiyle analiz etmişlerdir. Analizi mevduat bankalarının ortalamalarına kıyasla gerçekleştirmişlerdir. Analizde satın alınma sonrası dönemde yabancı bankalar tarafından satın alınan üç bankanın performansında azalış gerçekleştiği sonucuna ulaşmışlardır. Ancak yazarlar, satın alınma sonrası dönemlerin 2008 krizi sonrasına rastlamasının analiz sonuçlarını etkilediğini düşünmektedirler.

Gündoğdu (2017), 2015 yılı verilerine göre belirlemiş olduğu Türkiye'nin en büyük 10 mevduat bankasının 2005-2015 yılları arasındaki finansal performansını CAMELS derecelendirme sistemine göre analiz etmiştir. Çalışmada 2008 küresel finansal krizin bankacılık sektörüne etkisini ölçmeyi amaçlamıştır. Yapmış olduğu analizde sırası ile Akbank, Garanti Bankası, Ziraat Bankası, Halkbank, İs Bankası ve Vakıflar Bankası'nın olumlu performans gösterdiği; buna karşın sırası ile Finansbank, Denizbank, TEB, Yapı ve Kredi Bankası'nın ise kötü performans gösterdiği sonucuna ulaşmıştır.

Çelik (2018), Türkiye'de faaliyet gösteren 27 mevduat bankasını sahiplik yapısına ve aktif büyüklüğüne göre farklı gruplara ayırmış ve 2012-2016 yılları arasındaki performanslarını CAMELS puanları bazında ölçerek gruplar arasında karşılaştırma yapmıştır. Yapmış olduğu analizde sermaye yapısına göre yaptığı ayrımda, banka gruplarının benzer performans sergilediği sonucuna ulaşırken; aktif büyüklüguüne göre yaptığı ayrımda en küçük aktif büyüklügüne sahip 9 bankanın en büyük 9 ve ortanca 9 bankadan daha yüksek bir performansa sahip olduğu sonucuna ulaşmıştır. 
Baybaş Arslaner (2018), uzmanlık tezinde kamusal sermayeli 3 kalkınma ve yatırım bankasını CAMELS yöntemi ile analiz etmiştir. Çalışma 2012-2016 yılları arasını kapsamaktadır. Yazar, yapmış olduğu analizde ILBANK A.Ş.'nin sermaye yeterliliği, yönetim kalitesi, kârlılık ve piyasa riskine duyarlılık puanlarında diğerlerinden daha iyi bir performans sergilediği sonucuna ulaşmıştır. İLBANK A.Ş.'nin aynı zamanda hesaplanan bileşik CAMELS puanlarında da en iyi performansı gösteren banka olduğunu belirtmiştir. Yazar ayrıca, Türk Eximbank'ın sadece aktif kalitesi bileşeninde, Türkiye Kalkınma Bankası A.Ş.'nin ise likidite bileşeninde daha iyi performans sergilediği sonucuna ulaşmıştır.

Çizgici Akyüz ve Emir (2018), makroekonomik göstergelerin Türk Bankacılık Sektörü performansı üzerine etkilerini nedensellik analizi ile araştııı ilişkilerini ortaya koymuşlardır. Çalışmada, Türkiye'de faaliyette bulunan 22 mevduat bankasına ilişkin 2003:Q3-2016:Q2 dönemi verilerini kullanmışlardır. Performans değişkeni olarak ise, bankacılık sektörü bileşik CAMELS değerlerini kullanmışlardır. Çalışmada Türk Bankacılık Sektörü performansı ile tüketici fiyat endeksi ve faiz oranı arasında çift yönlü, gayri safi yurtiçi hâsıla ile tek yönlü nedensellik ilişkisi olduğu sonucuna ulaşmışlardır.

\section{Türkiye Ticari Bankacılık Sektörünün CAMELS Yöntemiyle Performans Analizi ve Derecelendirmesi}

Araştırmada kullanılan veri seti 2008-2018 yıllarında Türkiye'de kesintisiz faaliyet gösteren 3'ü kamu sermayeli, 9'u özel sermayeli, 12'si yabancı sermayeli olmak üzere toplam 24 mevduat bankasının Türkiye Bankalar Birliği tarafından yayınlanan finansal oranları ile yine aynı yıllarda Amerika'da faaliyet gösteren ticari bankaların FDIC (Federal Deposit Insurance Corporation) tarafından yayınlanan finansal oranlarıdır (TBB, 2019; FDIC, 2019).

\subsection{Araştırmanın Problemi}

Türkiye'de bankacılık sektörünün güçlü yapısı hem reel ekonomi hem de finans sektörünün gelişimi için büyük önem arz etmektedir. Bu nedenle sektörde görülen finansal eğilimlerin normal düzeylerde olup olmadığı, hangi bankaların daha iyi 
performansa sahip olduğu, performansı iyi olmayan bankaların performans iyileştirmesini nasıl yapabileceği bu araşsırmanın problemi olarak belirlenmiştir.

\subsection{Araştırmanın Amacı}

Araştırmada CAMELS performans analizi ve derecelendirme yöntemi kullanılarak, Türkiye'de 2008-2018 yıllarında sürekli faaliyet gösteren mevduat bankalarının Amerika'da faaliyet gösteren ticari bankalarla performans karşılaştırmasını yapmak ve ardından daha geniş kapsamlı finansal oranlarla bankalar bazında performans analizi yaparak performansı iyi olmayan bankalarda buna sebep olan sorunların tespit edilmesi ve iyileştirme için bu kapsamda çeşitli önerilerde bulunulması amaçlanmaktadır.

\subsection{Araştırmanın Kapsamı}

Araştırma Türkiye'de 2008-2018 yıllarında kesintisiz faaliyet gösteren 24 mevduat bankası ile sınırlandırılmıştır ve uluslararası karşılaştırma ise sadece Amerika'da faaliyet gösteren ve yine aynı yılları kapsayan ticari bankaların verileriyle yapılmıştır.

\subsection{Araştırmanın Yöntemi}

Araştırmada uluslararası finans piyasalarında performans ölçümü ve denetimi için yaygın kullanım alanına sahip olan CAMELS Derecelendirme ve Performans Analizi Yöntemi kullanılmıştır. CAMEL Derecelendirme Sistemi, 1970'lerin başında banka inceleme süreçlerinin yapılandırılmasına yardımcı olmak için Amerika'da federal düzenleyiciler ve denetleyiciler tarafından geliştirilmiştir (Siems ve Bar, 1998, s. 19). Illk olarak 1979 yllında FDIC (Federal Deposit Insurance Corporation Federal Mevduat Sigorta Kurumu) tarafindan UFIRS (Uniform Financial Institutions Rating System - Finansal Kuruluşlar Tek Düzen Derecelendirme Sistemi) adı altında kullanılmaya başlanmış ve daha sonra içerdiği 5 temel ölçüm faktörünün baş harfini alarak CAMEL (Capital adequacy, Asset quality, Management quality, Earnings ability and Liquidity) olarak yaygınlaşmıştır (Bergendorf ve Osback, 2017, s. 3). 
1996'dan bu yana riske daha fazla odaklanma gereğinin sonucu olarak, piyasa riskine duyarlılığı ifade eden S (Sensitivity) faktörü kullanılmaya başlanmış ve CAMELS yaklaşımına dönüşmüştür (Roman ve Şargu, 2013, s. 704). Yerinde bir banka denetiminin ardından banka denetçileri, altı CAMELS bileşeninin her biri için 1 (en iyi) ilâ 5 (en kötü) arasında puanlama sistemi kullanmaktadırlar. Ayrıca "bileşik - composite" puan olarak bilinen derecelendirme ölçüsü de kullanılmaktadır (Cole ve White, 2012, s. 6). Derecelendirme sisteminde 1 hiç riski olmayan ya da çok az risk barındıran ve finansal olarak sağlam bir bankayı ifade ederken, 5 büyük finansal sorunları olan ve muhtemelen iflasın eşiğinde olan bir bankayı ifade eder (Bergendorf ve Osback, 2017, s. 4). Buna göre (Türker Kaya, 2001, s. 1);

1. Finansal olarak her yönden güçlü banka olduğunu gösterir.

2. Genel olarak güçlü banka olduğunu gösterir. (Bir bankada her bir bileşenin puanının 1 ya da 2 olması beklenir.)

3. Bankanın finansal performansıyla ilgili bazı problemler yaşadığını, tatminkâr bir düzeyde çalışmadığını, olası şoklara karşı yeterince dayanıklı olmadığını gösterir. (Her bir bileşenin puanının 3'ten yukarı olmaması gerekir.)

4. Genel olarak ciddi problemleri olan, yönetimsel ve finansal performansı kötü olan bankayı gösterir.

5. Büyük finansal sorunlarla karşı karşıya olan ve batma riski taşıyan bankayı gösterir.

Çalışma kapsamında öncelikle Amerika'da 2008-2018 yılları aralığında faaliyet gösteren ticari bankaların CAMELS kapsamında belirlenen finansal oran ortalamaları ile Türkiye'de aynı yıllarda kesintisiz faaliyet gösteren mevduat bankalarının finansal oran ortalamaları belirlendikten sonra literatürden faydalanılarak finansal oran ile bileşen arasındaki ilişkinin yönü göz önünde bulundurularak oluşturulan puanlamaya tabii tutulacaktır. Bu bölümde kullanılacak olan finansal oranlar ve puanlama tablosu Tablo 2'de görüldüğü gibidir (Tabloda oranı temsilen R kullanılmıştır); 
Tablo 2: Finansal Oranlar ve CAMELS Puanlama Aralıkları

\begin{tabular}{|c|c|c|c|c|c|c|c|}
\hline \multirow{2}{*}{$\begin{array}{l}\text { Finansal } \\
\text { Oranlar }\end{array}$} & \multirow{2}{*}{$\begin{array}{c}\text { Oranın } \\
\text { Kodu }\end{array}$} & \multirow{2}{*}{$\begin{array}{l}\text { İlişkinin } \\
\text { Yönü }\end{array}$} & \multicolumn{5}{|c|}{ CAMELS Puanlama Aralığı } \\
\hline & & & 1 puan & 2 puan & 3 puan & 4 puan & 5 puan \\
\hline $\begin{array}{l}\text { C (Capital } \\
\text { Adequacy) Sermaye } \\
\text { Yeterliliği }\end{array}$ & C & & & & & & \\
\hline Sermaye Yeterlilik Rasyosu & SYR & + & $\mathrm{R} \geq 0,11$ & $0,11>R \geq 0,08$ & $0,08>R \geq 0,04$ & $0,04>R \geq 0,01$ & $0,01>\mathrm{R}$ \\
\hline $\begin{array}{l}\text { Özkaynaklar / Toplam } \\
\text { Aktifler }\end{array}$ & ÖZTA & + & $R \geq 0,10$ & $0,10>R \geq 0,06$ & $0,06>R \geq 0,04$ & $0,04>R \geq 0,02$ & $0,02>R$ \\
\hline $\begin{array}{l}\text { A (Asset Quality) } \\
\text { Aktif Kalitesi }\end{array}$ & A & & & & & & \\
\hline $\begin{array}{l}\text { Toplam Kredi ve } \\
\text { Alacaklar / Toplam } \\
\text { Aktifler }\end{array}$ & TKTA & - & $R \leq 0,50$ & $0,50<R \leq 0,60$ & $0,60<R \leq 0,65$ & $0,65<R \leq 0,70$ & $0,70<R$ \\
\hline $\begin{array}{l}\text { Takipteki Krediler } \\
\text { / Toplam Kredi ve } \\
\text { Alacaklar }\end{array}$ & TKTK & - & $R \leq 0,005$ & $0,005<R \leq 0,015$ & $0,015<R \leq 0,035$ & $0,035<R \leq 0,07$ & $0,07<R$ \\
\hline $\begin{array}{l}\text { M (Management } \\
\text { Quality) Yönetim } \\
\text { Kalitesi }\end{array}$ & M & & & & & & \\
\hline $\begin{array}{l}\text { Faaliyet Giderleri } \\
\text { / Toplam Kredi ve } \\
\text { Alacaklar }\end{array}$ & FGTK & - & $R \leq 0,06$ & $0,06<R \leq 0,08$ & $0,08<R \leq 0,11$ & $0,11<R \leq 0,14$ & $0,14<R$ \\
\hline $\begin{array}{l}\text { (Personel Gideri + Kıdem } \\
\text { Tazminatı) / Toplam } \\
\text { Aktifler }\end{array}$ & PGTA & - & $R \leq 0,015$ & $0,015<R \leq 0,02$ & $0,02<R \leq 0,025$ & $0,025<R \leq 0,03$ & $0,03<R$ \\
\hline $\begin{array}{l}\text { E (Earnings Ability) } \\
\text { Kârlılık }\end{array}$ & E & & & & & & \\
\hline $\begin{array}{l}\text { Ortalama Özkaynak } \\
\text { Kârlıı̆ı (ROE) }\end{array}$ & $\mathrm{ROE}$ & + & $R \geq 0,19$ & $0,19>R \geq 0,15$ & $0,15>R \geq 0,09$ & $0,09>R \geq 0,04$ & $0,04>R$ \\
\hline $\begin{array}{l}\text { Ortalama Aktif Kârlılığı } \\
\text { (ROA) }\end{array}$ & $\mathrm{ROA}$ & + & $R \geq 0,015$ & $0,015>R \geq 0,013$ & $0,013>R \geq 0,01$ & $0,01>R \geq 0,008$ & $0,008>R$ \\
\hline $\begin{array}{l}\text { L (Liquidity) Likidite } \\
\text { Durumu }\end{array}$ & L & & & & & & \\
\hline $\begin{array}{l}\text { Toplam Krediler / } \\
\text { Toplam Mevduat }\end{array}$ & TKTM & - & $R \leq 0,80$ & $0,80<R \leq 0,95$ & $0,95<R \leq 1$ & $1<R \leq 1,5$ & $1,5<\mathrm{R}$ \\
\hline $\begin{array}{l}\text { Toplam Yükümlülükler / } \\
\text { Toplam Aktifler }\end{array}$ & TYTA & - & $R \leq 0,70$ & $0,70<R \leq 0,80$ & $0,80<R \leq 0,85$ & $0,85<R \leq 0,90$ & $0,90<R$ \\
\hline $\begin{array}{l}\text { Toplam Mevduat / } \\
\text { Toplam Aktifler }\end{array}$ & TMTA & + & $R \geq 0,75$ & $0,75>R \geq 0,70$ & $0,70>R \geq 0,65$ & $0,65>R \geq 0,50$ & $0,50>R$ \\
\hline $\begin{array}{l}\text { S (Sensitivity to } \\
\text { Market Risk) Piyasa } \\
\text { Riskine Duyarlılık }\end{array}$ & $S$ & & & & & & \\
\hline $\begin{array}{l}\text { Toplam Risk Ağırlıkı } \\
\text { Varlıklar / Toplam Aktifler }\end{array}$ & RVTA & - & $R \leq 0,60$ & $0,60<R \leq 0,70$ & $0,70<R \leq 0,75$ & $0,75<R \leq 0,80$ & $0,80<R$ \\
\hline
\end{tabular}

Kaynak: Literatürden faydalanılarak yazar tarafından tasarlanmıştır. 
Amerikan ticari bankalarıyla karşılaştırmanın ardından daha geniş kapsamlı finansal oranlar kullanılarak Türkiye'de 2008-2018 yıllarında kesintisiz faaliyet gösteren mevduat bankalarının endeks değerleri üzerinden CAMELS performans analizleri ve puanlamaları yapılacaktır. Bu aşamada izlenecek adımlar aşağıdaki gibidir (Gündoğdu, 2017, s. 31; Çelik, 2018, s. 153; Ege, Topaloğlu ve Karakozak, 2015, s. 114; Kandemir ve Demirel Arıcı, 2013, s. 73);

1. Analizde kullanılacak finansal oranlar, finansal oranlar ile bileşenler arasındaki ilişkinin yönü ve oranların bileşenler içindeki ağırlıklarının belirlenmesi,

2. Çalışmada incelenecek 24 adet mevduat bankasının 2008-2018 dönemlerini kapsayan verilerinin ilk aşamada belirtilen finansal oranlar kapsamında hazırlanması,

3. Analizde kullanılan tüm bankaların her bir finansal oran bazında söz konusu yıllara ilişkin değerlerinin kırportalama (trimmean) ${ }^{5}$ metodu ile belirlenmesi ve referans değerlerin bulunması,

4. Her bir bankanın her yıl için ortaya çıkan oran değerlerinin o yılın referans değerine bölünmesi ve çıkan sonucun 100 ile çarpılması ile endeks değerlerinin hesaplanması,

5. Oran ile bileşen arasındaki ilişki pozitif yönlü olan endeks değerlerinden 100 çıkarılarak ve oran ile bileşen arasındaki ilişki negatif yönlü olan endeks değerlerini 100'den çıkararak sapma değerlerinin hesaplanması,

6. Her bir sapma değerinin oranın bileşen içindeki ağırlığıyla çarpılarak ağırlıklandırılması,

7. Ağırlıklandırılmış sapma değerlerin her bir bileşen bazında toplanması ve çıkan sonucun söz konusu bileşenin ağırlığıyla çarpımı ile sapma değerlerinin bileşen bazında ağırlıklandırılması,

8. Her bir yıl için bileşen bazında ağırlıklandırılmış sapma değerlerinin toplanması ve CAMELS endeks değerlerinin bulunması.

9. CAMELS endeks değerlerine göre bankaların puanlanması.

CAMELS endeks değerlerine göre puanlama sistemi aşağıdaki gibidir (Çelik, 2018, s. 154);

\footnotetext{
${ }^{5}$ Kırportalama (Trimmean): "Bir veri kümesinin yüksek ve düşük kısımlarından belirli oranda veriler hariç tutularak veri kümesinin ortalamasını hesaplar." (www.support.google.com)
} 


$$
\begin{array}{ll}
\text { CAMELS endeks değeri }<-30 & \rightarrow 5 \\
-30<\text { CAMELS Endeks değeri }<-10 & \rightarrow 4 \\
-10<\text { CAMELS Endeks değeri }<10 & \rightarrow 3 \\
10<\text { CAMELS Endeks değeri }<30 & \rightarrow 2 \\
30<\text { CAMELS Endeks değeri } & \rightarrow 1
\end{array}
$$

\subsection{Araştırmanın Bulguları ve Analizi}

Bu bölümde öncelikle Türkiye ve Amerika bankalarının karşılaştırılması yapılacak, ardından da Türkiye mevduat bankalarının performans analizi ve derecelendirmesi yapılacaktır.

\subsubsection{Amerika ve Türkiye Ticari Bankalarının Karşılaştırılması}

Araştırmanın ilk aşamasında 2008-2018 yıllarında Türkiye'de kesintisiz faaliyet gösteren 24 mevduat bankası ile Amerika'da aynı dönemlerde faaliyet gösteren ticaret bankalarının CAMELS performans analizi ve derecelendirme yöntemiyle karşılaştırmalı analizi gerçekleştirilecektir. Tablo 3'te her iki ülkenin bankalarının karşılaştırmada kullanılacak finansal oranları görülmektedir.

Tablo 3'te yer alan finansal oran ortalamaları bileşen bazında Tablo 2'de yer alan CAMELS puanlamalarına tabii tutulmuştur. Bu kapsamda C (Sermaye Yeterliliği) bileşeninin grafiği Grafik 4'te görüldüğü gibidir;

\section{Grafik 4. ABD ve TR Ticari Bankaları Sermaye Yeterliliği Karşılaştırması}

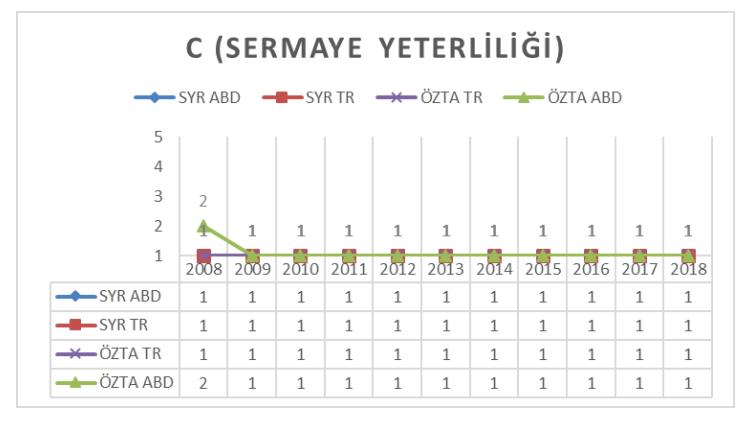

Kaynak: Yazar tarafından tasarlanmıştır. 


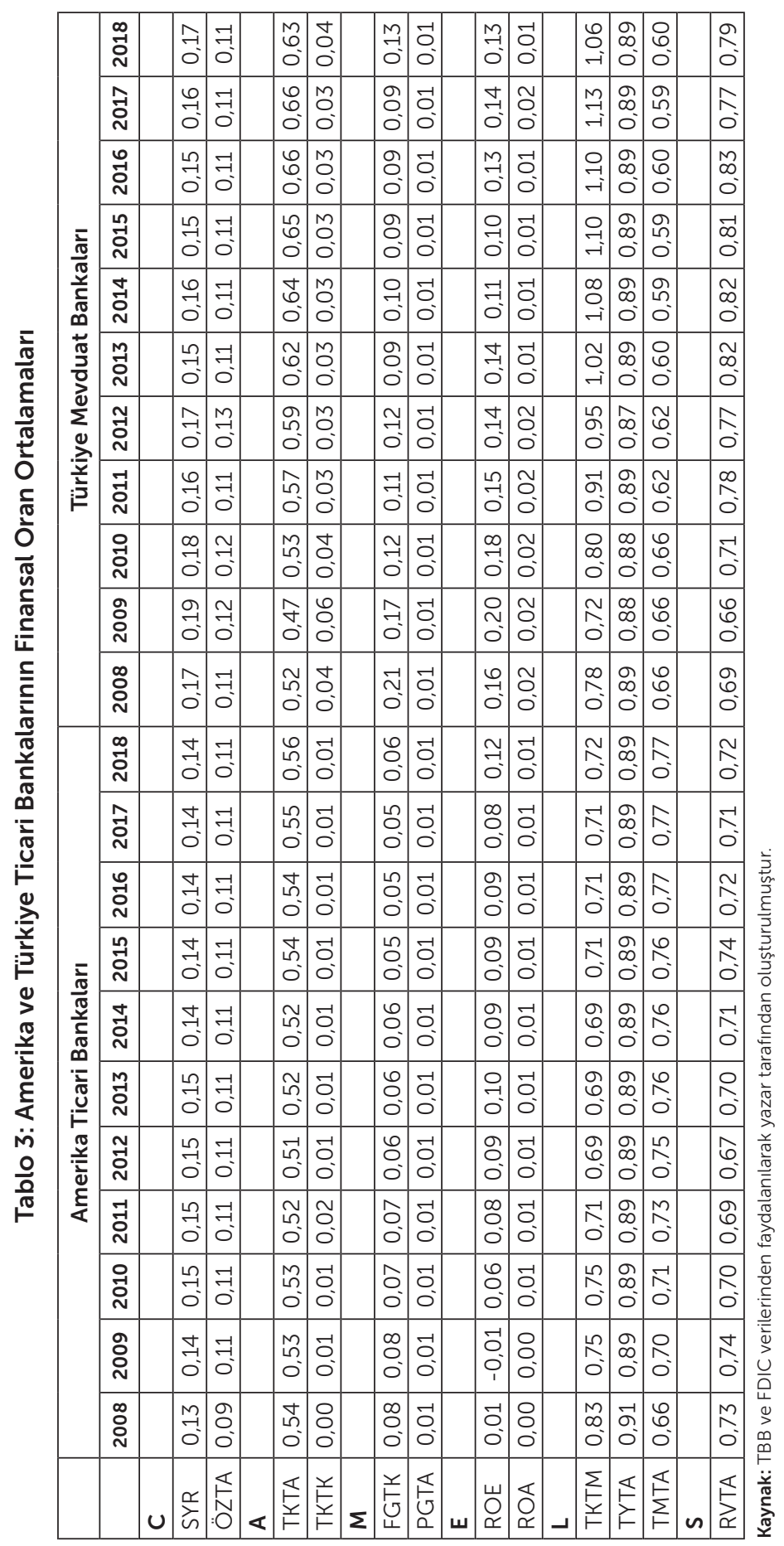


Grafik 4'te Türkiye bankalarının 10 yıllık süre boyunca sermaye yeterliliği puanı "1" olurken, Amerikan bankalarında 2008 yılında Öz kaynaklar/Toplam Aktifler oranında puanın "2"ye çıtığı ancak sonrasında dokuz yıl boyunca "1" puan olduğu görülmektedir. 2008 yılında Amerikan bankalarının öz kaynaklarında görülen bu azalmaya, 2007 yılının 3. çeyreğinde Amerika'da başlayan ve uluslararası literatüre "2008 krizi" olarak giren küresel finansal krizin (Engin ve Göllüce, 2016, s. 30) neden olmuş olabileceği söylenebilir.

\section{Grafik 5. ABD ve TR Ticari Bankaları Aktif Yeterliliği Karşılaştırması}

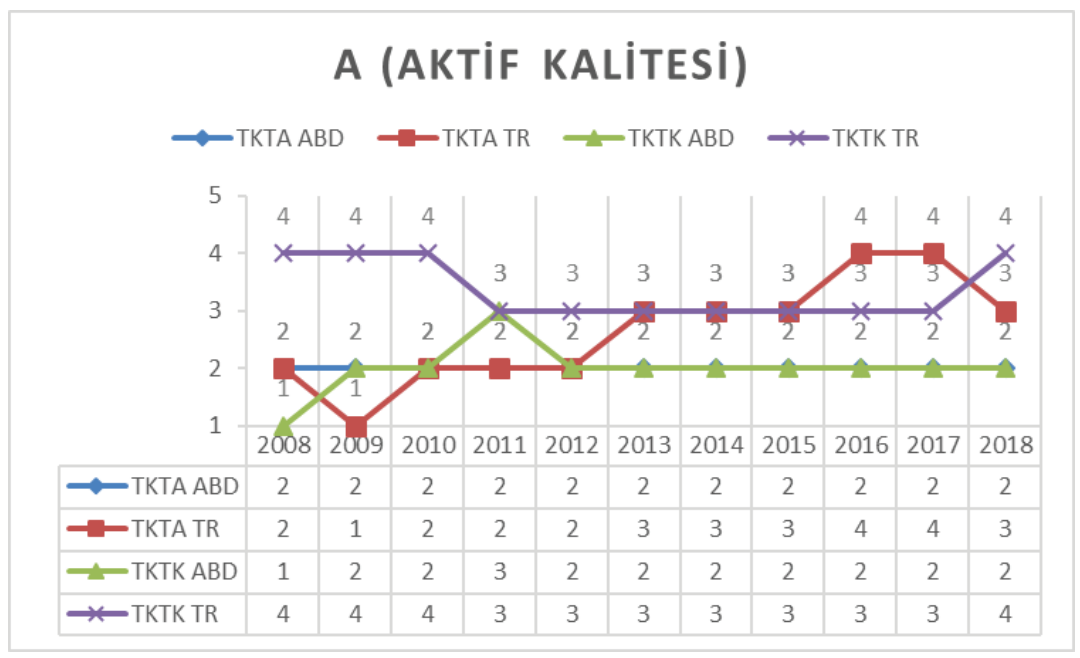

Kaynak: Yazar tarafından tasarlanmıştır.

Grafik 5'te toplam kredi ve alacakların toplam aktiflere oranı (TKTA) incelendiğinde, Amerikan bankalarında 11 yıllık süre boyunca 2 puanın üzerine çıkmadığı, dolayısıyla Amerikan bankalarının alacaklar konusunda temkinli davrandığı ve risk seviyesinin kabul edilebilir düzeyde olduğu söylenebilir. Ancak Türkiye bankaları için aynı şeyi söylemek mümkün değildir. Özellikle 2013 yılından sonra risk seviyesinin yükseldiği ve 2016 ve 2017 yıllarında kabul edilebilir sınırların üzerine çıktığı, 2018 yılında risk oranını düşürdügü görülse de oranın hâlâ yüksek olduğu söylenebilir. Nitekim Türkiye bankalarında alacaklar konusunda üstlenilen risk oranının yüksekliği, takipteki kredilerin toplam kredi ve alacaklar oranına (TKTK) bakıldığında da görülmektedir. 2008, 2009 ve 2010 yıllarında 
TKTA oranı istenilen düzeyde iken, takipteki kredilerin çok yüksek olduğu, 2010 sonrası biraz düzelme kaydedildiği ve 2018'de yeniden yüksek risk seviyelerine çıktığı görülmektedir. Bu durumda Türkiye bankalarının yüksek oranlarda kredi verdiğini ve kredilerin geri dönüşümü konusunda yetersiz kaldığını söyleyebiliriz.

\section{Grafik 6. ABD ve TR Ticari Bankaları Yönetim Kalitesi Karşılaştırması}

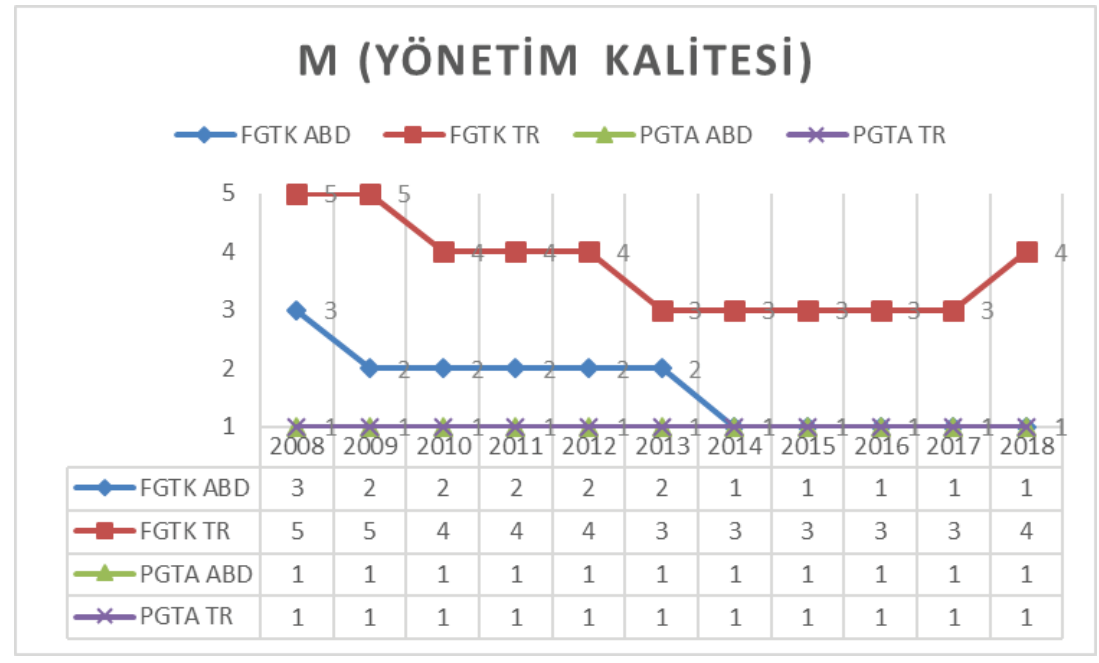

Kaynak: Yazar tarafından tasarlanmıştır

Grafik 6'da personel giderlerinin toplam aktiflere oranı (PGTA) her iki ülkede de istenilen seviyelerde görünmektedir. Ancak faaliyet giderlerinin toplam kredi ve alacaklara oranı (FGTK), Amerikan bankalarında istenilen seviyelerde görünmesine karşın, Türkiye bankalarında 2012 sonrası çok yüksek risk seviyelerinden kabul edilebilir seviyelere düşse de, 2018 yılında yeniden yüksek oranlı risk seviyelerine yükseldiği görülmektedir. 


\section{Grafik 7. ABD ve TR Ticari Bankaları Kârlılık Oranları Karşılaştırması}

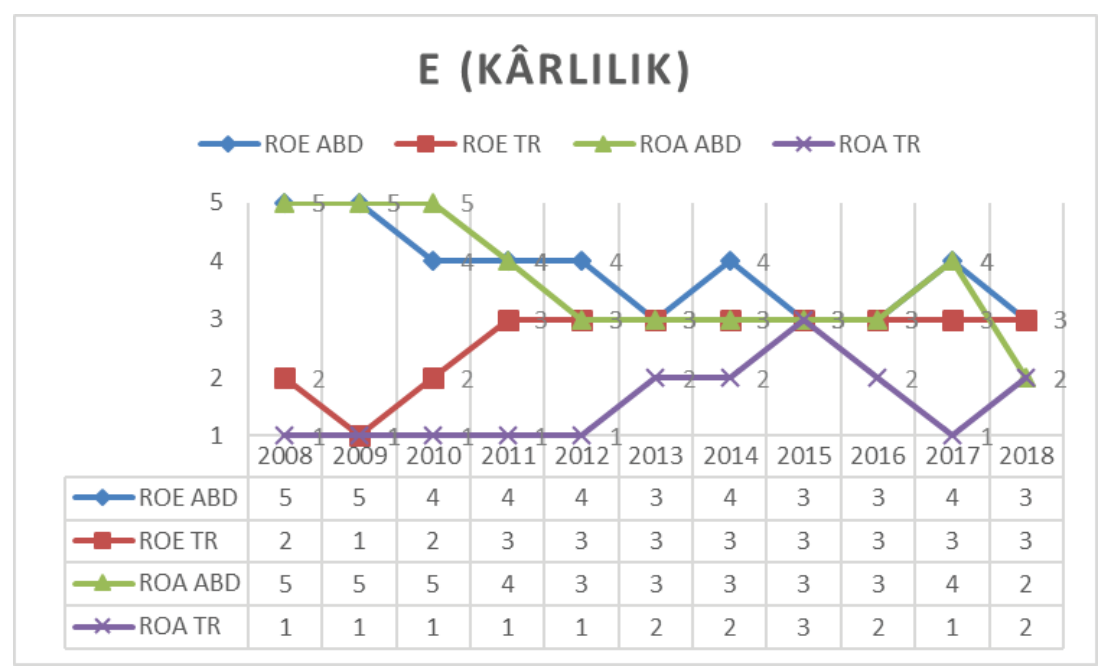

Kaynak: Yazar tarafından tasarlanmıştır.

Grafik 7'de ortalama öz kaynak kârlılığının (ROE) Amerikan bankalarında genel olarak düşük seyir ettiğini, özellikle 2010 sonrasında kabul edilebilir düzeylere çıkıp yeniden düştüğü görülmektedir. Amerikan bankalarının ortalama aktif kârlılı̆ında ise 2018 yılına kadar istenilen düzeylere çıkmadığı görülmektedir. Diğer taraftan Türkiye bankalarının özkaynak kârlılığında kabul edilebilir seviyelerde seyir izlediği, aktif kârlıı̆ıında ise, 2015 dışında, istenilen kârlılık düzeyini sürdürdüğü görülmektedir. 


\section{Grafik 8. ABD ve TR Ticari Bankaları Likidite Durumu Karşılaştırması}

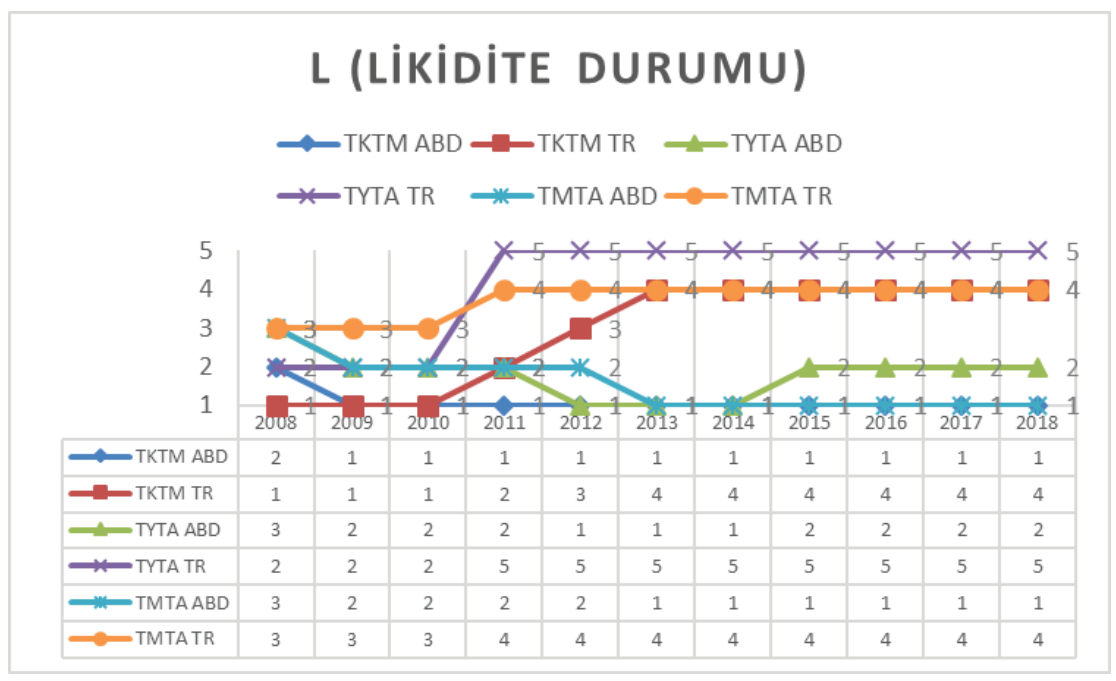

Kaynak: Yazar tarafından tasarlanmıştır.

Grafik 8'de toplam kredi ve alacakların toplam mevduatlara oranının (TKTM), Amerikan bankalarında istenilen düzeylerde seyir ederken, Türkiye bankalarında 2013 sonrası yüksek seviyelerde risk barındırdığı görülmektedir. Toplam yükümlülüklerin toplam aktiflere oranı incelendiğinde ise, Amerikan bankalarında yine istenilen düzeylerde risk üstlenildiği ancak Türkiye bankalarında özellikle 2011 sonrası çok yüksek risk seviyelerinin sürdürüldügü görülmektedir. Toplam mevduatların toplam aktiflere oranı (TMTA) incelendiğinde ise, yine Amerikan bankalarında istenilen düzeyde seyir görülürken, Türkiye bankalarında mevduatların aktiflere oranı yetersiz görünmekte ve bu nedenle yüksek risk seviyeleri sürdürülmektedir. Bu durumda Türkiye bankalarının likidite durumu açısından çok yüksek riskler barındırdığı, borçlarını ödemekte zorlanabileceği söylenebilir. 


\section{Grafik 9. ABD ve TR Ticari Bankaları Risk Duyarlıı̆ı Karşılaştırması}

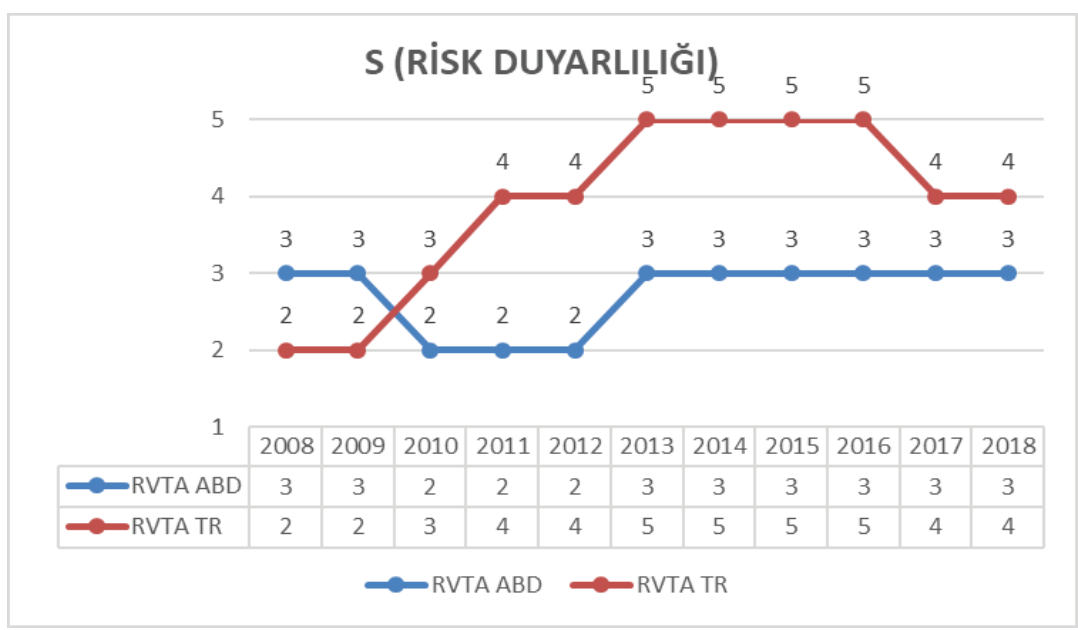

Kaynak: Yazar tarafından tasarlanmıştır.

Grafik 9'da toplam risk ağırlıklı varlıkların toplam varlıklara oranının (RVTA), Amerikan bankalarında kabul edilebilir sınırlarda ilerlediği ancak Türkiye bankalarında bu oranın yüksek oranda risk barındırdığı görülmektedir.

\section{Grafik 10. ABD ve TR Ticari Bankaları Ortalama CAMELS Puanları}

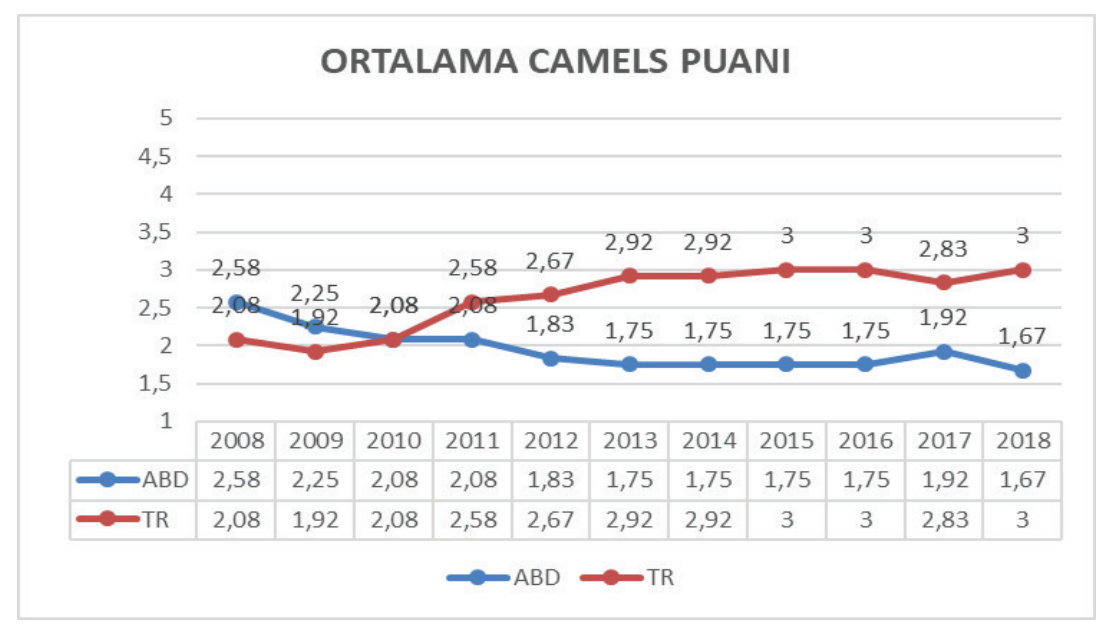

Kaynak: Yazar tarafından tasarlanmıştır 
Grafik 10 'da her iki ülkenin ortalama her yıl için ayrı ayrı ortalama CAMELS puanları görülmektedir. Buna göre Amerika ticari bankaları 2008 yılı sonrasında eğilimi sürekli 1-2 puan aralığındadır. CAMELS puan değerlendirme sistemine göre, Amerika bankalarının genel olarak güçlü bir finansal performans gösterdiğini söyleyebiliriz. Türkiye bankalarında ise 2009 yılı sonrasında eğilimin sürekli olarak 2-3 puan aralığında olduğu, ancak puanların genel olarak 3 ya da 3 sınırına yakın olduğu görülmektedir. CAMELS puan değerlendirme sistemine göre, Türkiye bankalarının finansal performansla ilgili bazı sıkıntılar yaşadığını, olası şoklara karşı yeterince savunma geliştiremeyeceğini söyleyebiliriz.

\subsubsection{Türkiye Ticari Bankalarının CAMELS Performans Analizleri ve Puanlamaları}

Çalışmanın bundan sonraki aşamasında daha geniş kapsamlı finansal oranlar kullanılarak, 2008-2018 yıllarında Türkiye'de kesintisiz faaliyet gösteren 24 mevduat bankasının endeks değerleri üzerinden CAMELS performans analizleri ve puanlamaları yapılacaktır. Bu kapsamda çalışmanın ilk adımını oluşturan finansal oranlar, finansal oranlar ile bileşenler arasındaki ilişkinin yönü ve oranların bileşenler içindeki ağırlıkları Tablo 4'te görüldüğü gibidir;

Tablo 4: Finansal Oranlar ve Ağırlıkları

\begin{tabular}{|l|c|c|c|c|}
\hline Finansal Oranlar & $\begin{array}{c}\text { Oranın } \\
\text { Kodu }\end{array}$ & $\begin{array}{c}\text { ilişkinin } \\
\text { Yönü }\end{array}$ & $\begin{array}{c}\text { Bileşen } \\
\text { Ağırlığı } \\
\text { (\%) }\end{array}$ & $\begin{array}{c}\text { Finansal } \\
\text { Oran } \\
\text { Ağırlığı (\%) }\end{array}$ \\
\hline C (Capital) Sermaye Yeterliliği & C & & 20 & \\
\hline Sermaye Yeterlilik Rasyosu & SYR & + & & 25 \\
\hline Özkaynaklar/Toplam Aktifler & ÖZTA & + & & 20 \\
\hline (Özkaynaklar-Duran Varlıklar)/Toplam Aktifler & ÖZDVA & + & & 20 \\
\hline Net Bilanço Pozisyonu/Özkaynaklar & NBPÖZ & - & & 20 \\
\hline Özkaynaklar/(Mevduat+Mevduat Dışı Kaynaklar) & ÖZMEK & + & & 15 \\
\hline A (Asset) Aktif Kalitesi & A & & 20 & \\
\hline Finansal Varlıklar (Net)/Toplam Aktifler & FVTA & - & & 15 \\
\hline Toplam Krediler ve Alacaklar / Toplam Aktifler & TKTA & - & & 20 \\
\hline Duran Varlıklar / Toplam Aktifler & DVA & - & & 10 \\
\hline Takipteki Krediler/Toplam Kredi ve Alacaklar & TKTKA & - & & 20 \\
\hline Toplam Kredi ve Alacaklar/Toplam Mevduat & TKAM & - & & 15 \\
\hline
\end{tabular}




\begin{tabular}{|l|c|c|c|c|}
\hline Tüketici Kredileri/Toplam Kredi ve Alacaklar & TÜKTKA & - & & 20 \\
\hline M (Management Quality) Yönetim Kalitesi & M & & 15 & \\
\hline $\begin{array}{l}\text { (Personel Gideri+Kıdem Tazminatı/Toplam } \\
\text { Aktifler }\end{array}$ & PGTA & - & & 15 \\
\hline Personel Giderleri/Diğer Faaliyet Giderleri & PGDFG & - & & 15 \\
\hline Toplam Faaliyet Gelirleri/Toplam Aktifler & TFGTA & + & & 30 \\
\hline Diğer Faaliyet Giderleri/Toplam Aktifler & DFGTA & - & & 10 \\
\hline Faiz Dışı Gelirler (Net)/Diğer Faaliyet Giderleri & FDGDFG & + & & 30 \\
\hline E (Earnings) Kârlılık & E & & 15 & \\
\hline Ortalama Aktif Kârlı̆ı̆ı (ROA) & ROA & + & & 25 \\
\hline Ortalama Özkaynak Kârlılı̆ı (ROE) & ROE & + & & 25 \\
\hline Vergi Öncesi Kâr/Toplam Aktifler & VÖKTA & + & & 25 \\
\hline Dönem Net Kârı/Ödenmiş Sermaye & DKZS & + & & 25 \\
\hline L (Liquidity) Likidite Durumu & L & & 15 & \\
\hline Likit Aktifler/Toplam Aktifler & LATA & + & & 30 \\
\hline Likit Aktifler/Kısa Vadeli Yabancı Kaynaklar & LAKVYK & + & & 30 \\
\hline Türk Parası Likit Aktifler/Toplam Aktifler & TPLATA & + & & 15 \\
\hline Yabancı Para Likit Aktifler/Yabancı Para Pasifler & YPLAYP & + & & 25 \\
\hline $\begin{array}{l}\text { S (Sensitivity to Market Risk) Piyasa Riskine } \\
\text { Duyarlılık }\end{array}$ & S & & 15 & \\
\hline Alınan Krediler/Toplam Aktifler & AKTA & - & & 10 \\
\hline $\begin{array}{l}\text { Özel Karşılıklar Sonrası Net Faiz Geliri/Toplam } \\
\text { Aktifler }\end{array}$ & NFGTA & + & & 10 \\
\hline Türk Parası Aktifler/Toplam Aktifler & TPATA & + & & 10 \\
\hline $\begin{array}{l}\text { Türk Parası Yükümlülükler /Toplam } \\
\text { Yükümlülükler }\end{array}$ & TPYTY & + & & 10 \\
\hline Yabancı Para Aktifler/Yabancı Para Pasifler & YPAYPP & + & & 15 \\
\hline Türk Parası Mevduat/Toplam Mevduat & TPMTM & + & & 10 \\
\hline Toplam Mevduat/Toplam Aktifler & FDGTA & - & & 10 \\
\hline Türk Parası Krediler/Toplam Krediler & + & & 10 \\
\hline Faiz Dışı Gelirler (Net)/Toplam Aktifler & + & & 10 \\
\hline
\end{tabular}

Kaynak: Literatürden faydalanılarak yazar tarafından oluşturulmuştur.

Çalışmada incelenecek 24 adet mevduat bankası Tablo 5 'te görüldüğü gibidir ve 2. adımda belirtilen, 2008-2018 dönemini kapsayan banka verileri alan sınırlaması dolayısıyla tek tek gösterilememiş ancak Ziraat Bankası verileri örnek olarak Ek-1'de gösterilmiştir; 
Tablo 5: Analizde Kullanılan Mevduat Bankalarının Listesi

\begin{tabular}{|l|l|l|}
\hline $\begin{array}{l}\text { Kamu Sermayeli Mevduat } \\
\text { Bankaları }\end{array}$ & $\begin{array}{l}\text { Özel Sermayeli Mevduat } \\
\text { Bankaları }\end{array}$ & Yabancı Sermayeli Bankalar \\
\hline T.C. Ziraat Bankası & Adabank A.Ş. & Alternatifbank A.Ş. \\
\hline $\begin{array}{l}\text { Türkiye Vakıflar Bankası } \\
\text { T.A.O. }\end{array}$ & Akbank T.A.Ş. & Arap Türk Bankası A.Ş. \\
\hline Türkiye Halk Bankası A.Ş. & Anadolubank A.Ş. & $\begin{array}{l}\text { Burgan Bank A.Ş. (Eurobank } \\
\text { Tekfen) }\end{array}$ \\
\hline & $\begin{array}{l}\text { Fibabanka A.Ş. (Millenium } \\
\text { Bank) }\end{array}$ & Citibank A.Ş. \\
\hline & Şekerbank T.A.Ş. & Denizbank A.Ş. \\
\hline & Turkish Bank A.Ş. & Deutsche Bank A.Ş. \\
\hline & Türk Ekonomi Bankası A.Ş. & HSBC Bank A.Ş. \\
\hline & Türkiye İş Bankası A.Ş. & $\begin{array}{l}\text { ICBC Turkey Bank A.Ş. (Tekstil } \\
\text { Bankası) }\end{array}$ \\
\hline & Yapı ve Kredi Bankası A.Ş. & ING Bank A.Ş. \\
\hline & & QNB Finansbank A.Ş. \\
\hline & & Turkland Bank A.Ş. \\
\hline & $\begin{array}{l}\text { Garanti BBVA (Türkiye Garanti } \\
\text { Bankası A.Ş.) }\end{array}$ \\
\hline
\end{tabular}

Tablo 5'te görüldüğü gibi çalışma kapsamında 3 adet kamu bankası, 9 adet özel sermayeli banka ve 12 adet yabancı sermayeli banka incelenmiştir. Söz konusu bankalardan bazıları 2008-2018 yılları arasında isim ya da yönetim değişikliğine gitseler de kesintisiz faaliyet gösterdikleri için çalışma kapsamına alınmışlardır.

CAMELS endeks değeri hesaplamasında üçüncü adım olan referans değerleri hesaplama tablosu Ek-2'de gösterilmiştir. Referans değerleri hesaplamasında her bir oranın söz konusu yıllara ilişkin verileri kırportalama (trimmean) yöntemi ile hesaplanmıştır.

İkinci adımdan sonra yapılan hesaplamalar yer sınırlılığı dolayısıyla adım adım gösterilemeyeceği için, Tablo 6'da Ziraat Bankası için 2018 yılı verileri üzerinden yapılan hesaplamalar örnek olarak gösterilmiştir. 
Tablo 6: Ziraat Bankası 2018 yılı CAMELS Endeks Puanı

\begin{tabular}{|c|c|c|c|c|c|c|}
\hline $\begin{array}{l}\text { Oran } \\
\text { Kodları }\end{array}$ & $\begin{array}{l}\text { Endeks } \\
\text { Değerleri }\end{array}$ & $\begin{array}{c}\text { Sapma } \\
\text { Değerleri }\end{array}$ & $\begin{array}{l}\text { Ağırlıklandırıımış } \\
\text { Sapma Değerleri }\end{array}$ & $\begin{array}{c}\text { Sapma } \\
\text { Değerlerin } \\
\text { Bileşen } \\
\text { Bazında } \\
\text { Toplanması }\end{array}$ & $\begin{array}{l}\text { Sapma Değerlerin } \\
\text { Bileşen Bazında } \\
\text { Ağırlıklandırılması }\end{array}$ & $\begin{array}{l}\text { CAMELS } \\
\text { ENDEKS } \\
\text { DEĞERI }\end{array}$ \\
\hline C & & & & \multirow{6}{*}{$-5,79$} & \multirow{6}{*}{$-1,16$} & \multirow{39}{*}{$-10,67$} \\
\hline SYR & 77,4 & $-22,59$ & $-5,65$ & & & \\
\hline ÖZTA & 92,7 & $-7,29$ & $-1,46$ & & & \\
\hline ÖZDVA & 94,6 & $-5,38$ & $-1,08$ & & & \\
\hline NBPÖZ & 77,4 & 22,56 & 4,51 & & & \\
\hline ÖZMEK & 85,9 & $-14,13$ & $-2,12$ & & & \\
\hline \multicolumn{4}{|l|}{ A } & \multirow{7}{*}{$-3,59$} & \multirow{7}{*}{$-0,72$} & \\
\hline FVTA & 73,7 & 26,25 & 3,94 & & & \\
\hline TKTA & 118,2 & $-18,15$ & $-3,63$ & & & \\
\hline DVA & 88,1 & 11,86 & 1,19 & & & \\
\hline ТКТКА & 41,4 & 58,61 & 11,72 & & & \\
\hline TKAM & 117,5 & $-17,45$ & $-2,62$ & & & \\
\hline TÜKTKA & 171,0 & $-70,95$ & $-14,19$ & & & \\
\hline \multicolumn{4}{|l|}{$M$} & \multirow{6}{*}{$-18,70$} & \multirow{6}{*}{$-2,80$} & \\
\hline PGTA & 47,6 & 52,35 & 7,85 & & & \\
\hline PGDFG & 83,6 & 16,37 & 2,46 & & & \\
\hline TFGTA & 76,7 & $-23,27$ & $-6,98$ & & & \\
\hline DFGTA & 55,1 & 44,95 & 4,49 & & & \\
\hline FDGDFG & 11,6 & $-88,40$ & $-26,52$ & & & \\
\hline$E$ & & & & \multirow{5}{*}{27,94} & \multirow{5}{*}{4,19} & \\
\hline $\mathrm{ROA}$ & 101,5 & 1,50 & 0,38 & & & \\
\hline ROE & 122,4 & 22,44 & 5,61 & & & \\
\hline VÖKTA & 97,1 & $-2,94$ & $-0,73$ & & & \\
\hline DKZS & 190,7 & 90,75 & 22,69 & & & \\
\hline \multicolumn{4}{|l|}{$L$} & \multirow{5}{*}{$-60,93$} & \multirow{5}{*}{$-9,14$} & \\
\hline LATA & 39,6 & $-60,38$ & $-18,11$ & & & \\
\hline LAKVYK & 31,3 & $-68,75$ & $-20,62$ & & & \\
\hline TPLATA & 16,5 & $-83,52$ & $-12,53$ & & & \\
\hline YPLAYP & 61,3 & $-38,66$ & $-9,66$ & & & \\
\hline \multicolumn{4}{|l|}{$S$} & \multirow{10}{*}{$-6,91$} & \multirow{10}{*}{$-1,04$} & \\
\hline AKTA & 65,6 & 34,45 & 3,44 & & & \\
\hline NFGTA & 98,9 & $-1,05$ & $-0,11$ & & & \\
\hline TPATA & 107,6 & 7,59 & 0,76 & & & \\
\hline TPYTY & 116,2 & 16,18 & 1,62 & & & \\
\hline YPAYPP & 106,6 & 6,62 & 0,99 & & & \\
\hline TPMTM & 111,9 & 11,95 & 1,19 & & & \\
\hline TMTA & 99,5 & $-0,55$ & $-0,05$ & & & \\
\hline TPKTK & 110,9 & $-10,92$ & $-1,09$ & & & \\
\hline FDGTA & 8,9 & $-91,10$ & $-13,67$ & & & \\
\hline
\end{tabular}

Kaynak: TBB verilerinden faydalanılarak yazar tarafından hazırlanmıştır.

Tablo 7'de her bir mevduat bankasının her yıl için hesaplanan CAMELS puanları ve toplam CAMELS puanlarının ortalaması görülmektedir. 
Tablo 7: Yıllara Göre Mevduat Bankaları CAMELS Puanları

\begin{tabular}{|c|c|c|c|c|c|c|c|c|c|c|c|}
\hline \multirow[b]{2}{*}{ BANKA İSIMLERI } & \multicolumn{11}{|c|}{ CAMELS Puanları } \\
\hline & $\stackrel{\infty}{\circ}$ & : & 웅 & ন্ণ & 궁 & $\stackrel{m}{\stackrel{N}{N}}$ & ষ্ণ & 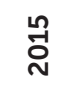 & $\stackrel{0}{\circ}$ & ન્̀ & $\stackrel{\infty}{\stackrel{్}{ }}$ \\
\hline \multicolumn{12}{|c|}{ Kamu Sermayeli Mevduat Bankaları } \\
\hline T.C. Ziraat Bankası & 2 & 2 & 2 & 3 & 3 & 2 & 2 & 2 & 2 & 2 & 4 \\
\hline Türkiye Halk Bankası A.Ş. & 3 & 3 & 2 & 2 & 2 & 2 & 2 & 2 & 3 & 2 & 3 \\
\hline $\begin{array}{l}\text { Türkiye Vakıflar Bankası } \\
\text { T.A.O. }\end{array}$ & 3 & 3 & 3 & 3 & 3 & 3 & 3 & 3 & 3 & 3 & 3 \\
\hline \multicolumn{12}{|c|}{ Özel Sermayeli Mevduat Bankaları } \\
\hline Adabank A.Ş. & 1 & 1 & 1 & 1 & 1 & 1 & 1 & 1 & 1 & 1 & 1 \\
\hline Akbank T.A.Ş. & 3 & 2 & 2 & 2 & 3 & 3 & 3 & 3 & 3 & 2 & 3 \\
\hline Anadolubank A.Ş. & 4 & 4 & 4 & 4 & 3 & 3 & 3 & 3 & 3 & 3 & 1 \\
\hline $\begin{array}{l}\text { Fibabanka A.Ş. (Millennium } \\
\text { Bank) }\end{array}$ & 5 & 5 & 5 & 5 & 4 & 4 & 4 & 4 & 4 & 3 & 3 \\
\hline Şekerbank T.A.Ş. & 3 & 3 & 3 & 3 & 3 & 3 & 4 & 3 & 3 & 3 & 4 \\
\hline Turkish Bank A.Ş. & 1 & 2 & 2 & 2 & 2 & 3 & 3 & 3 & 3 & 4 & 3 \\
\hline Türk Ekonomi Bankası A.Ş. & 4 & 4 & 3 & 4 & 4 & 4 & 4 & 3 & 3 & 3 & 3 \\
\hline Türkiye İş Bankası A.Ş. & 2 & 2 & 2 & 3 & 3 & 3 & 3 & 3 & 3 & 3 & 4 \\
\hline Yapı ve Kredi Bankası A.Ş. & 4 & 4 & 3 & 4 & 4 & 3 & 3 & 3 & 3 & 3 & 4 \\
\hline \multicolumn{12}{|l|}{ Yabancı Sermayeli Bankalar } \\
\hline Alternatifbank A.Ş. & 3 & 4 & 4 & 4 & 4 & 4 & 4 & 4 & 4 & 4 & 3 \\
\hline Arap Türk Bankası A.Ş. & 5 & 5 & 4 & 2 & 2 & 2 & 1 & 2 & 2 & 2 & 2 \\
\hline $\begin{array}{l}\text { Burgan Bank A.Ş. (Eurobank } \\
\text { Tekfen) }\end{array}$ & 3 & 3 & 4 & 3 & 3 & 4 & 4 & 4 & 4 & 4 & 4 \\
\hline Citibank A.Ş. & 1 & 1 & 1 & 2 & 1 & 1 & 1 & 1 & 1 & 1 & 1 \\
\hline Denizbank A.Ş. & 4 & 4 & 4 & 3 & 3 & 3 & 3 & 3 & 3 & 3 & 4 \\
\hline Deutsche Bank A.Ş. & 1 & 1 & 1 & 3 & 1 & 3 & 2 & 3 & 2 & 3 & 2 \\
\hline HSBC Bank A.Ş. & 4 & 4 & 3 & 3 & 4 & 3 & 3 & 4 & 4 & 3 & 3 \\
\hline $\begin{array}{l}\text { ICBC Turkey Bank A.Ş. } \\
\text { (Tekstil Bankası) }\end{array}$ & 4 & 4 & 4 & 4 & 4 & 3 & 4 & 5 & 5 & 5 & 4 \\
\hline ING Bank A.Ş. & 4 & 5 & 5 & 4 & 4 & 4 & 4 & 4 & 4 & 4 & 3 \\
\hline QNB Finansbank A.Ş. & 3 & 3 & 4 & 3 & 4 & 4 & 4 & 4 & 3 & 4 & 4 \\
\hline Turkland Bank A.Ş. & 5 & 5 & 5 & 5 & 5 & 5 & 5 & 5 & 5 & 5 & 5 \\
\hline $\begin{array}{l}\text { Garanti BBVA (Türkiye } \\
\text { Garanti Bankası A.Ş.) }\end{array}$ & 3 & 2 & 2 & 3 & 3 & 3 & 3 & 3 & 3 & 3 & 3 \\
\hline CAMELS Puan Ortalaması & 3,13 & 3,17 & 3,04 & 3,13 & 3,04 & 3,04 & 3,04 & 3,13 & 3,08 & 3,04 & 3,08 \\
\hline
\end{tabular}

Kaynak: TBB verilerinden faydalanılarak yazar tarafından hazırlanmışıı.

Tabloya göre 2008-2018 yıllarında kesintisiz faaliyet gösteren mevduat bankalarının CAMELS puanı ortalaması bütün yıllar için 3 puanın üzerinde seyir göstermiştir. Bu durumda CAMELS puan değerlendirme sistemine göre, söz 
konusu bankalar risk açısından kabul edilebilir düzeyde bulunsalar da finansal performansla ilgili bazı sıkıntılar yaşamaktadırlar ve kriz anlarında savunmasız kalabilirler denilebilir.

Tablo 7 verilerine göre gruplar bazında değerlendirme yapıldığında, Kamu Sermayeli Mevduat Bankaları arasında en iyi performans seyrini, 2018 yılında 3 puana yükselmiş olsa da, Halk Bankası göstermektedir denilebilir. Özel Sermayeli Mevduat Bankalarında ise en iyi performans gösteren bankanın Adabank olduğu ve Anadolu Bank'ın da onu takip ettiği söylenebilir. Ancak Şekerbank, Türkiye İş Bankası ve Yapı ve Kredi Bankası'nın 2018 yılında 4 puana çıktıkları, dolayısıyla ciddi finansal problemlerle karşı karşıya oldukları söylenebilir. Yabancı Sermayeli Bankalar grubunda ise en iyi performans gösteren bankanın Citibank olduğu, Arap Türk Bankası'nın onu takip ettiği, en kötü performans gösteren bankanın da Bank olduğu söylenebilir. Diğer taraftan Burgan Bank, QNB Finansbank, ICBC Turkey Bank'ın çok riskli seviyelerde faaliyetlerine devam ettiği söylenebilir. Denizbank için de 2018 yılında çok yüksek risk seviyelerine yeniden çıkmış olduğu söylenebilir.

Yine tabloya göre bankalar CAMELS performans puanları üzerinden genel olarak değerlendirildiğinde ise, tüm yıllarda 1 puan performansını gösteren Adabank ve Citibank için finansal olarak her yönden güçlü banka oldukları ve mevduat bankaları arasında en iyi performansı gösteren bankalar oldukları söylenebilir. Diğer taraftan Bank için de, tüm yıllarda göstermiş olduğu 5 puan seyrinden dolayı, büyük finansal sorunlarla ve batma riskiyle karşı karşıya olduğu söylenebilir. Dolayısıyla mevduat bankaları arasında en kötü performansı gösteren banka Bank'tır denilebilir. Tabloda en dikkat çekici noktalardan biri de iyi bir performans seyrinde hareket eden Ziraat Bankası'nın 2018 ylında 4 puanla ciddi finansal problemleri olan bir bankaya dönüşmesidir. Anadolu Bank içinse tam tersi söylenebilir. Zira 4 puan gibi risk oranı yüksek seviyelerden 2018 yılında her yönden güçlü bankaya dönüşmüştür.

Performans düşüklügü gösteren bankalar ayrı ayrı incelendiğinde aşağıdaki sonuçlarla karşılaşılmıştır; 
- Ziraat Bankası'nın 2018 yılında likidite problemiyle karşı karşıya kaldığı ve toplam aktifler içerisinde toplam faaliyet gelirleri oranının düştüğü tespit edilmiştir.

- Şekerbank T.A.Ş.'nin 2018 yılında sermaye yeterliliği, yönetim kalitesi, kârlılık ve likidite problemleriyle karşı karşıya kaldığı tespit edilmiştir.

- Işs Bankası́nın 2011 sonrasında sürekli aktif kalitesi ve likidite problemlerinin olduğu, 2018 yılında ise toplam aktifler içerisindeki faaliyet gelirleri oranının düştüğü tespit edilmiştir.

- Yapı Kredi Bankası'nın 2008 yılından itibaren sürekli aktif kalitesi ve likidite problemleriyle karşı karşıya olduğu, 2017 sonrasında da piyasa riskine duyarlılı̆ının arttığı tespit edilmiştir.

- Burgan Bank'ın 2008 yılından itibaren sürekli kârlılık problemiyle karşı karşıya olduğu, 2012 yılından sonra yönetim kalitesi ve likidite problemlerinin ortaya çıktığı, 2013 yılından sonra ise piyasa riskine duyarlılığının arttığı tespit edilmiştir.

- Denizbank'ın 2008 yılından beri aktif kalitesi ve likidite problemlerinin olduğu, 2018 yılında ise sermaye yeterliliği problemiyle karşılaştığı tespit edilmiştir.

- ICBC Turkey Bank'ın 2008 yılından beri yönetim kalitesi, kârlılık ve likidite problemlerinin olduğu, 2016 sonrasında ise sermaye yeterliliği problemiyle karşılaştığı tespit edilmiştir.

- QNB Finansbank'ın aktif kalitesi ve piyasa riskine duyarlılık problemleriyle karşı karşıya olduğu, 2012 sonrasında likidite problemiyle karşılaştığı tespit edilmiştir.

- Turkland Bank'ın 2008 yılından beri yönetim kalitesi, kârlılık ve piyasa riskine duyarlılık problemleriyle karşı karşıya olduğu ve 2018 yılında sermaye yeterliliği ve likidite problemleriyle karşılaştığı tespit edilmiştir.

- Garanti Bankası'nın ise, 2008 yllından beri aktif kalitesi problemleriyle karşı karşıya olduğu ve 2013 sonrasında ise likidite problemiyle karşılaştı̆̆ı tespit edilmiştir.

\section{Sonuç ve Öneriler}

Bu çalışma, CAMELS performans analizi ve derecelendirme yöntemini kullanarak, Türkiye'de 2008-2018 yıllarında sürekli faaliyet gösteren mevduat 
bankalarının Amerika'da faaliyet gösteren ticari bankalarla performans karşılaştırmasını yapmayı ve ardından, daha geniş kapsamlı finansal oranlarla, mevduat bankaları bazında performans analizi yapmayı ve performansı iyi olmayan bankalarda buna sebep olan sorunların tespit edilmesini ve çeşitli önerilerde bulunulmasını amaçlamaktadır. Bu kapsamda, 2008-2018 yıllarında Türkiye'de kesintisiz faaliyet gösteren 24 mevduat bankasının Türkiye Bankalar Birliği tarafından yayınlanan finansal oranları ile yine aynı yıllarda Amerika'da faaliyet gösteren ticari bankaların FDIC (Federal Deposit Insurance Corporation) tarafından yayınlanan finansal oranları kullanılarak analiz gerçekleştirilmiştir.

Amerika ticari bankaları ile yapılan performans analizi karşılaştırması sonucuna göre; Amerikan bankalarının genel olarak 1-2 puanlık CAMELS puanıla güçlü finansal performans gösterdiği, buna karşın Türkiye mevduat bankalarının genel olarak 3 puanlık CAMELS puanıyla kabul edilebilir sınırlar dâhilinde olsa da performansla ilgili sorunlar yaşadığı ve olası şoklara karşı yeterince savunma geliştiremeyeceği düşünülmektedir. Zira CAMELS bileşenleri bazında inceleme yapıldığında, Türkiye bankalarının yüksek oranlarda kredi verdiği ve kredilerin geri dönüşümü konusunda yetersiz kaldığı, faaliyet giderlerinin toplam kredi ve alacaklarına oranının yüksek olduğu, giderlerin özellikle 2018 yılında yüksek oranlı risk seviyelerine yükseldiği, likidite açısından çok yüksek seviyede riskler barındırdığı ve bu risk düzeyini sürdürdüğü tespit edilmiştir.

Türkiye mevduat bankaları için CAMELS endeks değerleri üzerinden yapılan performans karşılaştırmasında ise bankaların genel olarak, Amerika bankaları ile karşılaştırmada olduğu gibi, risk açısından kabul edilebilir durumda bulunsalar da finansal performansla ilgili bazı sıkıntılar yaşadığı ve kriz anlarında savunmasız kalabilecekleri sonucuna ulaşılmıştır.

Bankalar gruplar bazında değerlendirildiğinde, kamu sermayeli bankalar arasında en iyi performans göstergesinin Halk Bankası'nda olduğu, Ziraat Bankası'nın ise 2018 yılında performans düşüklüğü kaydettiği görülmüştür. Özel sermayeli bankalar arasında en iyi performans göstergesinin Adabank'ta olduğu, Şekerbank, Türkiye İş Bankası ve Yapı Kredi Bankası'nın da 2018 yılında performans 
düşüklüğü kaydettiği tespit edilmiştir. Yabancı sermayeli bankalar arasında ise, en iyi performans göstergesinin Citibank'da olduğu, Burgan Bank, QNB Finansbank, ICBC Turkey Bank'ın çok riskli seviyelerde faaliyetlerine devam ettiği, Denizbank'ın ise 2018 yılında çok yüksek risk seviyelerine yeniden çıtı̆̆ı tespit edilmiştir.

Risk düzeyi yüksek olan bankalar ayrı ayrı incelendiğinde ise, söz konusu bankaların genel olarak likidite problemleriyle karşı karşıya olduğu, toplam aktifler içerisindeki faaliyet gelirleri oranlarını düşürdükleri, toplam kredi ve alacaklarının yükseldiği ve takipteki kredilerin ise artış gösterdiği sonucuna ulaşılmıştır.

Çalışmada hem Amerikan bankalarıyla yapılan performans karşılaştırması sonucunda hem de sadece Türk bankaları için yapılan performans analizi sonucunda hemen hemen aynı sonuçlara ulaşılmıştır. Bu nedenle Türkiye'de faaliyet gösteren mevduat bankalarına öncelikle kredi ve alacaklar konusunda temkinli olmaları önerilmektedir. Zira kredilerin geri dönüşü uygun seviyelerde olursa likidite problemlerinin de yönetim kalitesi problemlerinin de azaltılacağı düşünülmektedir.

Bu çalışmanın çeşitli kısıtları bulunmaktadır. Araştırmanın sadece mevduat bankalarını kapsaması ve uluslararası karşılaştırmanın ise sadece Amerika'da faaliyet gösteren ticari bankalarla yapılması önemli bir kısıtıı. Ayrıca araştırmaya konu olan verilerin belirli bir döneme ait olması da diğer bir kısıt olarak kabul edilebilir. İleride yapılacak çalışmalarda bankacılık sektörünün bütününü kapsaması ve uluslararası karşılaştırmanın daha fazla ülke ile yapılması bu çalışmanın test edilebilirliği açısından önemli olacaktır. Çalışmanın bu yönüyle literatürün gelişmesine ve derinleşmesine katkı sunması ve ayrıca profesyonel uygulayıcılara yardımcı olması beklenmektedir. 
Hakem Değerlendirmesi: Dış bağımsız.

Çıkar Çatışması: Yazar çıkar çatışması bildirmemiștir.

Finansal Destek: Yazar bu çalışma için finansal destek almadığını beyan etmiştir.

Peer-review: Externally peer-reviewed.

Conflict of Interest: The author has no conflict of interest to declare.

Grant Support: The author declared that this study has received no financial support.

\section{Kaynaklar/References}

Ateşoğlu Coşkun, S. ve Karğın, S. (2016). Sınır ötesi birleşme ve satın almaların bankaların finansal performansına etkileri: üç banka üzerinde CAMELS analizi, Muhasebe ve Finansman Dergisi, 69, 41-60.

Baybaş Arslaner, Y. (2018). Türk Kalkınma ve Yatırım Bankacılık Sektöründe Performans (CAMELS) Analizi. (uzmanlık tezi). Iller Bankası Anonim Şirketi, Ankara.

BDDK. (2019, 27 Aralık). Ayllk bankacıllk sektörü verileri (temel gösterim). Erişim adresi: https://www. bddk.org.tr/BultenAylik.

Bergendorff, I. and Osbäck, M. (2017). Banking Soundness in The European Union - The Impact of The Capital Requirements Regulation. (Master dissertation, Jönköping University, Jönköping). Retrieved from https://www.kisa.link/NmDm.

Cole, R. and White, L. (2012). Déjà vu all over again: the causes of U.S. commercial bank failures this time around, Journal of Financial Services Research, 42(1), 5-29.

Çelik, M. (2018). Türkiye'de faaliyet gösteren mevduat bankalarının performans analizi: büyüklük ve sahiplik yapısı ayrımıyla bir karşılaştırma. Mehmet Akif Ersoy Üniversitesi İktisadi ve İdari Bilimler Fakültesi Dergisi, 5 (2), 146-168.

Çizgici Akyüz, G. ve Emir, M. (2018). Makroekonomik göstergelerin Türk bankacılık sektörü performansı üzerine etkileri, Uluslararası İktisadi ve İdari Incelemeler Dergisi, Prof. Dr. Harun TERZi Özel Sayısı, 1-20.

Dang, U. (2011). The CAMEL rating system in banking supervision. (A case study, Arcada University of Applied Sciences, International Business Degree Programme). Retrieved from https://www. kisa.link/NmDz.

Desta, T. S. (2016). Financial performance of "the best African banks": a comparative analysis through CAMEL rating. Journal of Accounting and Management, 6 (1), 1-20.

Ege, İ., Topaloğlu, E. E. ve Karakozak, Ö. (2015). CAMELS performans değerleme modeli: Türkiye'deki mevduat bankaları üzerine ampirik bir uygulama. Niğde Üniversitesi İktisadi ve İdari Bilimler Fakültesi Dergisi, 8 (4), 109-126.

Emiral, F., (2002), Türk bankacılık sisteminde etkinlik analizi (veri zarflama analizi uygulaması), Deloitte, Mayıs-Haziran Raporu.

Engin, C. ve Göllüce, E. (2016). 2008 küresel finans krizi ve Türkiye üzerine yansımaları. Kahramanmaraş Sütçü Imam Üniversitesi Iktisadi ve Idari Bilimler Fakültesi Dergisi, 6 (1), 27-40.

FDIC (Federal Deposit Insurance Corporation). (2019, 28 Aralık). FDIC - Statistics on depository institutions report. Erişim adresi: https://www.kisa.link/NmDF. 
Gündoğdu, A. (2017). Türkiye'de mevduat bankalarının CAMELS analizi. Bankacılık ve Finansal Araştırmalar Dergisi (BAFAD), 4 (2), 26-43.

Kandemir, T. ve Demirel Arıcı, N. (2013). Mevduat bankalarında CAMELS performans değerleme modeli üzerine karşılaştırmalı bir çalışma (2001-2010). Süleyman Demirel Üniversitesi Iktisadi ve İdari Bilimler Fakültesi Dergisi, 18 (1), 61-87.

Kartal, M. T. (2018). Bankaların finans sektöründeki önemi. Erişim adresi: http://0fs.me/7704196.

Keffala, M. R. (2018). Analyzing the effect of derivatives on the financial soundness of commercial banks in Italy: An approach based on the CAMELS framework. Review of Finacial Economics, 36 (3), 267-283.

Keskin, E., İnan, E. A. ve Ünsal, Ü. (2019). 60. Yılında Türkiye Bankalar Birliği ve Türkiye'de Bankacılık Sistemi 1958-2018. İstanbul: Türkiye Bankalar Birliği, Yayın No: 334.

Majithiya, R. ve Pattani, A. (2010). Rating the performance of the bank through CAMELS model. (A Project Report, Tolani Institute of Management Studies)

Masood, O., Ghauri, S. M. K. \& Aktan, B. (2016). Predicting Islamic banks performance through CAMELS rating model. Banks and Bank Systems, 11 (3), 37-43.

Ünal, M. (2014). Türkiye'de Finans Sektöründe Bankacılığın Yeri. İzmir Ticaret Odası Ar-Ge Bülteni Ekonomi, Eylül 2014.

Öztürk, N., Barışık, S. ve Kılıç Darıcı, H. (2010). Gelişmekte olan piyasalarda finansal derinleşme ve büyüme ilişkisi: panel veri analizi. ZKÜ Sosyal Bilimler Dergisi, 6 (12), 95-119.

Roman, A. and Şargu, A. C. (2013). Analysing the financial soundness of the commercial banks in Romania: an approach based on the CAMELS framework. Procedia Economics and Finance, 6, 703-712.

Siems, T. F. and Barr, R. S. (1998). Benchmarking the productive efficiency of U.S. banks, Federal Reserve Bank of Dallas Financial Industry Studies, December, 11-24.

TBB (Türkiye Bankalar Birliği), (2019), Türkiye'de bankacıllk sistemi seçilmiş rasyolar (2008-2018), Rapor Kodu: YT05. Erişim adresi: https://www.kisa.link/NmDR.

TCMB. (2020, 6 Ocak). Gösterge niteliğindeki Merkez Bankası kurları. Erişim adresi: https://bit. ly/2ulQWOU.

TUiK $_{1}$. (2020: 6 Ocak). Tüketici fiyat endeks rakamları (2003=100). Erişim adresi: https://bit. ly/2ty016C.

TUIK $_{2}$. (2019: 27 Aralık). Temel Istatistikler, Erişim adresi: https://www.kisa.link/NmDS.

Türker Kaya, Y. (2001). Türk bankacılık sektöründe CAMELS analizi, BDDK MSPD Çalışma Raporları: 2001/6

Zedan, K. A. ve Daas, K. (2017). Palestinian banks analysis using CAMEL model. International Journal of Economics and Financial Issues, 7(1), 351-357.

www.inflationdata.com. (2020, 6 Ocak). Historical inflation rate. Retrieved from: https://bit. ly/2MYpSfb.

www.support.google.com. (2020, 2 Nisan). Kırportalama (Trimmean), Erişim adresi: https://www. kisa.link/N8po. 


\section{EKLER}

\section{EK-1}

\begin{tabular}{|c|c|c|c|c|c|c|c|c|c|c|c|}
\hline & \multicolumn{11}{|c|}{ Ziraat Bankası Rasyoları } \\
\hline & 2008 & 2009 & 2010 & 2011 & 2012 & 2013 & 2014 & 2015 & 2016 & 2017 & 2018 \\
\hline \multicolumn{12}{|l|}{$\mathbf{C}$} \\
\hline SYR & 0,201 & 0,232 & 0,192 & 0,156 & 0,190 & 0,132 & 0,182 & 0,151 & 0,145 & 0,152 & 0,148 \\
\hline ÖZTA & 0,071 & 0,083 & 0,089 & 0,082 & 0,105 & 0,089 & 0,115 & 0,104 & 0,107 & 0,108 & 0,107 \\
\hline ÖZDVA & 0,055 & 0,069 & 0,077 & 0,069 & 0,088 & 0,072 & 0,085 & 0,075 & 0,077 & 0,081 & 0,080 \\
\hline NBPÖZ & 0,003 & $-0,004$ & $-0,132$ & $-0,088$ & $-0,077$ & $-0,145$ & $-0,066$ & $-0,026$ & 0,263 & $-0,198$ & $-0,340$ \\
\hline ÖZMEK & 0,085 & 0,102 & 0,100 & 0,092 & 0,123 & 0,101 & 0,136 & 0,121 & 0,125 & 0,127 & 0,126 \\
\hline \multicolumn{12}{|l|}{$\mathbf{A}$} \\
\hline FVTA & 0,560 & 0,570 & 0,505 & 0,440 & 0,402 & 0,303 & 0,261 & 0,214 & 0,193 & 0,166 & 0,267 \\
\hline TKTA & 0,295 & 0,295 & 0,380 & 0,445 & 0,439 & 0,535 & 0,573 & 0,617 & 0,650 & 0,687 & 0,691 \\
\hline DVA & 0,020 & 0,019 & 0,016 & 0,017 & 0,025 & 0,024 & 0,038 & 0,037 & 0,041 & 0,038 & 0,027 \\
\hline TKTKA & 0,020 & 0,023 & 0,015 & 0,012 & 0,029 & 0,022 & 0,019 & 0,017 & 0,018 & 0,016 & 0,020 \\
\hline TKAM & 0,368 & 0,373 & 0,457 & 0,632 & 0,600 & 0,783 & 0,926 & 1,002 & 1,043 & 1,120 & 1,120 \\
\hline TÜKTKA & 0,431 & 0,456 & 0,406 & 0,425 & 0,404 & 0,336 & 0,297 & 0,269 & 0,269 & 0,280 & 0,245 \\
\hline \multicolumn{12}{|l|}{ M } \\
\hline PGTA & 0,009 & 0,009 & 0,009 & 0,009 & 0,009 & 0,009 & 0,008 & 0,007 & 0,006 & 0,006 & 0,005 \\
\hline PGDFG & 0,531 & 0,552 & 0,549 & 0,501 & 0,481 & 0,482 & 0,445 & 0,397 & 0,431 & 0,384 & 0,369 \\
\hline TFGTA & 0,048 & 0,056 & 0,045 & 0,039 & 0,050 & 0,048 & 0,043 & 0,044 & 0,048 & 0,046 & 0,036 \\
\hline DFGTA & 0,017 & 0,015 & 0,015 & 0,016 & 0,017 & 0,018 & 0,017 & 0,017 & 0,015 & 0,015 & 0,014 \\
\hline FDGDFG & 0,512 & 0,462 & 0,670 & 0,369 & 0,434 & 0,582 & 0,515 & 0,516 & 0,616 & 0,472 & 0,109 \\
\hline \multicolumn{12}{|l|}{$\mathbf{E}$} \\
\hline ROA & 0,023 & 0,031 & 0,027 & 0,013 & 0,016 & 0,018 & 0,018 & 0,019 & 0,020 & 0,020 & 0,016 \\
\hline ROE & 0,293 & 0,396 & 0,312 & 0,158 & 0,175 & 0,187 & 0,173 & 0,172 & 0,188 & 0,186 & 0,152 \\
\hline VÖKTA & 0,026 & 0,035 & 0,030 & 0,017 & 0,022 & 0,021 & 0,021 & 0,022 & 0,024 & 0,024 & 0,019 \\
\hline DKZS & 0,854 & 1,404 & 1,485 & 0,840 & 1,060 & 1,332 & 1,620 & 1,032 & 1,289 & 1,418 & 1,305 \\
\hline \multicolumn{12}{|l|}{$\mathbf{L}$} \\
\hline LATA & 0,219 & 0,327 & 0,363 & 0,335 & 0,374 & 0,367 & 0,351 & 0,316 & 0,289 & 0,260 & 0,086 \\
\hline LAKVYK & 0,307 & 0,443 & 0,496 & 0,446 & 0,570 & 0,573 & 0,581 & 0,512 & 0,461 & 0,421 & 0,140 \\
\hline TPLATA & 0,119 & 0,231 & 0,290 & 0,251 & 0,242 & 0,215 & 0,199 & 0,157 & 0,149 & 0,120 & 0,011 \\
\hline YPLAYP & 0,615 & 0,621 & 0,477 & 0,494 & 0,597 & 0,511 & 0,472 & 0,462 & 0,445 & 0,386 & 0,186 \\
\hline \multicolumn{12}{|l|}{$\mathbf{S}$} \\
\hline AKTA & 0,000 & 0,000 & 0,001 & 0,003 & 0,019 & 0,041 & 0,059 & 0,065 & 0,064 & 0,067 & 0,064 \\
\hline NFGTA & 0,037 & 0,046 & 0,035 & 0,031 & 0,037 & 0,034 & 0,032 & 0,032 & 0,033 & 0,036 & 0,032 \\
\hline TPATA & 0,838 & 0,845 & 0,860 & 0,837 & 0,792 & 0,716 & 0,694 & 0,665 & 0,659 & 0,665 & 0,627 \\
\hline TPYTY & 0,838 & 0,844 & 0,847 & 0,829 & 0,780 & 0,703 & 0,678 & 0,656 & 0,684 & 0,637 & 0,594 \\
\hline YPAYPP & 1,001 & 0,997 & 0,915 & 0,957 & 0,946 & 0,954 & 0,952 & 0,976 & 1,080 & 0,923 & 0,920 \\
\hline ТРМТМ & 0,803 & 0,807 & 0,822 & 0,789 & 0,776 & 0,710 & 0,702 & 0,647 & 0,672 & 0,608 & 0,538 \\
\hline TMTA & 0,803 & 0,791 & 0,832 & 0,704 & 0,730 & 0,683 & 0,619 & 0,616 & 0,623 & 0,613 & 0,616 \\
\hline TPKTK & 0,960 & 0,944 & 0,905 & 0,901 & 0,896 & 0,814 & 0,778 & 0,755 & 0,726 & 0,744 & 0,679 \\
\hline FDGTA & 0,008 & 0,007 & 0,010 & 0,006 & 0,008 & 0,010 & 0,009 & 0,009 & 0,009 & 0,007 & 0,001 \\
\hline
\end{tabular}

Kaynak: TBB verilerinden faydalanılarak yazar tarafından oluşturulmuştur. 


\section{EK-2}

\begin{tabular}{|c|c|c|c|c|c|c|c|c|c|c|c|}
\hline & \multicolumn{11}{|c|}{ Referans Değerleri } \\
\hline & 2008 & 2009 & 2010 & 2011 & 2012 & 2013 & 2014 & 2015 & 2016 & 2017 & 2018 \\
\hline \multicolumn{12}{|l|}{$\mathrm{C}$} \\
\hline SYR & 0,198 & 0,215 & 0,194 & 0,175 & 0,191 & 0,159 & 0,167 & 0,157 & 0,164 & 0,169 & 0,191 \\
\hline ÖZTA & 0,148 & 0,149 & 0,138 & 0,122 & 0,144 & 0,117 & 0,119 & 0,113 & 0,110 & 0,114 & 0,115 \\
\hline ÖZDVA & 0,105 & 0,110 & 0,105 & 0,094 & 0,113 & 0,090 & 0,090 & 0,082 & 0,080 & 0,082 & 0,084 \\
\hline NBPÖZ & $-0,150$ & $-0,296$ & $-0,348$ & $-0,287$ & $-0,273$ & $-0,386$ & $-0,459$ & $-0,466$ & $-0,244$ & $-0,662$ & $-0,438$ \\
\hline ÖZMEK & 0,225 & 0,204 & 0,173 & 0,150 & 0,190 & 0,143 & 0,146 & 0,138 & 0,135 & 0,140 & 0,147 \\
\hline \multicolumn{12}{|l|}{$\mathbf{A}$} \\
\hline FVTA & 0,246 & 0,285 & 0,222 & 0,196 & 0,164 & 0,150 & 0,124 & 0,125 & 0,133 & 0,123 & 0,363 \\
\hline TKTA & 0,517 & 0,504 & 0,542 & 0,555 & 0,584 & 0,600 & 0,624 & 0,637 & 0,626 & 0,646 & 0,584 \\
\hline DVA & 0,059 & 0,065 & 0,053 & 0,044 & 0,046 & 0,041 & 0,045 & 0,048 & 0,049 & 0,050 & 0,031 \\
\hline TKTKA & 0,036 & 0,059 & 0,043 & 0,032 & 0,033 & 0,030 & 0,031 & 0,034 & 0,035 & 0,034 & 0,049 \\
\hline TKAM & 0,848 & 0,797 & 0,876 & 0,934 & 0,956 & 1,030 & 1,056 & 1,109 & 1,061 & 1,104 & 0,954 \\
\hline TÜKTKA & 0,251 & 0,262 & 0,253 & 0,237 & 0,240 & 0,211 & 0,193 & 0,171 & 0,163 & 0,154 & 0,143 \\
\hline \multicolumn{12}{|l|}{ M } \\
\hline PGTA & 0,020 & 0,019 & 0,017 & 0,015 & 0,016 & 0,013 & 0,013 & 0,012 & 0,012 & 0,011 & 0,012 \\
\hline PGDFG & 0,489 & 0,491 & 0,464 & 0,479 & 0,468 & 0,464 & 0,457 & 0,439 & 0,444 & 0,452 & 0,442 \\
\hline TFGTA & 0,070 & 0,078 & 0,062 & 0,051 & 0,062 & 0,050 & 0,051 & 0,048 & 0,050 & 0,048 & 0,048 \\
\hline DFGTA & 0,040 & 0,038 & 0,038 & 0,030 & 0,033 & 0,028 & 0,028 & 0,027 & 0,026 & 0,024 & 0,026 \\
\hline FDGDFG & 0,464 & 0,552 & 0,570 & 0,540 & 0,520 & 0,486 & 0,460 & 0,399 & 0,526 & 0,353 & 0,939 \\
\hline \multicolumn{12}{|l|}{ E } \\
\hline ROA & 0,017 & 0,019 & 0,016 & 0,012 & 0,014 & 0,010 & 0,012 & 0,011 & 0,012 & 0,014 & 0,016 \\
\hline ROE & 0,124 & 0,148 & 0,117 & 0,099 & 0,120 & 0,091 & 0,102 & 0,084 & 0,100 & 0,117 & 0,125 \\
\hline VÖKTA & 0,019 & 0,022 & 0,018 & 0,013 & 0,018 & 0,011 & 0,014 & 0,012 & 0,014 & 0,016 & 0,019 \\
\hline DKZS & 0,285 & 0,434 & 0,392 & 0,312 & 0,471 & 0,422 & 0,451 & 0,396 & 0,511 & 0,662 & 0,684 \\
\hline \multicolumn{12}{|l|}{ L } \\
\hline LATA & 0,311 & 0,349 & 0,343 & 0,352 & 0,336 & 0,322 & 0,306 & 0,294 & 0,306 & 0,282 & 0,217 \\
\hline LAKVYK & 0,562 & 0,572 & 0,552 & 0,590 & 0,620 & 0,596 & 0,626 & 0,599 & 0,557 & 0,517 & 0,448 \\
\hline TPLATA & 0,186 & 0,242 & 0,260 & 0,229 & 0,207 & 0,167 & 0,156 & 0,119 & 0,121 & 0,115 & 0,064 \\
\hline YPLAYP & 0,341 & 0,307 & 0,255 & 0,325 & 0,368 & 0,379 & 0,346 & 0,363 & 0,388 & 0,349 & 0,303 \\
\hline \multicolumn{12}{|l|}{$\mathrm{S}$} \\
\hline AKTA & 0,128 & 0,109 & 0,117 & 0,112 & 0,097 & 0,118 & 0,113 & 0,132 & 0,113 & 0,124 & 0,097 \\
\hline NFGTA & 0,042 & 0,043 & 0,037 & 0,034 & 0,039 & 0,031 & 0,033 & 0,030 & 0,028 & 0,034 & 0,032 \\
\hline TPATA & 0,730 & 0,768 & 0,783 & 0,731 & 0,739 & 0,688 & 0,681 & 0,626 & 0,615 & 0,634 & 0,583 \\
\hline TPYTY & 0,622 & 0,656 & 0,667 & 0,653 & 0,655 & 0,597 & 0,581 & 0,528 & 0,543 & 0,517 & 0,512 \\
\hline YPAYPP & 0,765 & 0,717 & 0,712 & 0,817 & 0,776 & 0,783 & 0,772 & 0,799 & 0,844 & 0,778 & 0,863 \\
\hline TPMTM & 0,581 & 0,584 & 0,642 & 0,646 & 0,655 & 0,615 & 0,599 & 0,551 & 0,554 & 0,505 & 0,481 \\
\hline TMTA & 0,602 & 0,614 & 0,619 & 0,601 & 0,610 & 0,586 & 0,592 & 0,576 & 0,596 & 0,591 & 0,620 \\
\hline TPKTK & 0,769 & 0,765 & 0,754 & 0,728 & 0,773 & 0,723 & 0,723 & 0,688 & 0,682 & 0,700 & 0,612 \\
\hline FDGTA & 0,016 & 0,019 & 0,020 & 0,014 & 0,015 & 0,012 & 0,012 & 0,010 & 0,013 & 0,007 & 0,011 \\
\hline
\end{tabular}

Kaynak: TBB verilerinden faydalanılarak yazar tarafından oluşturulmuştur. 